\title{
A Grande Saúde: uma introdução à medicina do Corpo sem Órgãos
}

Ricardo Rodrigues Teixeira ${ }^{1}$

TEIXEIRA, R. R. The Great Health: an introduction to the Body without Organs medicine, Interface Comunic., Saude, Educ., v.8, n.14, p.35-72, set.2003-fev.2004.

Availing oneself of Spinoza's Ethics as a starting point and especially of the interpretation of his philosophy according to Deleuze \& Guattari, we propose the frame of reference of Grand Health and outline what medicine based on this idea might consist of. Another concept proposed is that of the Body With No Organs, conceived to deal with the plane on which Grand Health is experienced: the plane of intensities experienced as an ongoing fluctuation of powers, appetites and desires. This Deleuzian interpretation of Spinoza allows us to glimpse the basis for a hypothetical Spinozistic medicine, with its Physiology of the Body With No Organs, its "pathology", understood herein as Affectology, its "science of signals and symptoms" or Semiotics and what might be its "therapeutics", governed by the ideal of Grand Health.

KEY WORDS: Health; Philosophy; Ethics.

Partindo da Ética de Espinosa e, especialmente, das leituras de sua filosofia praticadas por Deleuze E Guattari, propomos o conceito referencial de Grande Saúde e esboçamos o que poderia ser a medicina referenciada nessa concepção. Outro conceito proposto é o de Corpo sem Órgãos, para dar conta do plano em que se experimenta a Grande Saúde: plano de intensidades vivido como variação contínua das potências, do apetite, do desejo. Essa leitura deleuzeana de Espinosa, permite-nos entrever as bases de uma hipotética medicina espinosana, com sua Fisiologia do Corpo sem Órgãos, sua "patologia", aqui entendida como Afectologia, sua "ciência dos sinais e sintomas" ou Semiótica e o que seria sua "terapêutica” orientada pelo ideal da Grande Saúde.

PALAVRAS-CHAVE: Saúde; Filosofia; Ética.

${ }^{1}$ Médico sanitarista, docente e pesquisador do Centro Saúde Escola Samuel B. Pessoa, São Paulo; Departamento de Medicina Preventiva da Faculdade de Medicina da Universidade de São Paulo (FM/USP).<ricarte@usp.br> 
Os primeiros dois ou três dias que se seguiram ao naufrágio foram marcados pelo profundo abatimento de Robinson que, apesar de ter sobrevivido à catástrofe, tomava plena consciência da miserável condição em que se encontrava. Seu ânimo, em cacos, flutuava entre a esperança de avistar, a qualquer momento, no horizonte, uma nau, e o mais descabelado desespero. Fundamentalmente, seu ânimo sucumbia à força dos acontecimentos que, ora, tomavam o comando de seu destino. Sucumbia à força das avassaladoras causas externas que lhe sobrevinham. Sua tristeza quase só lhe deixava o facho suficiente para vigiar o vazio oceânico se estendendo por todos os lados.

Mas - como escreve, com lucidez poética, Mia Couto (1992) -, "a festa é a tristeza no pino". E é no zênite da tristeza e do abandono mais absoluto que se ergue em Robinson, também em seu ponto mais alto, todo o esforço de perseverar em ser, que - como se verá a seguir - é a mesma coisa que sua potência própria de agir e de pensar.

Espinosa, no século XVII, chamava de conatus a esse esforço feito por cada coisa para perseverar em seu ser (proposição 6, livro 3: "Da origem e natureza dos afetos", Ética) e que é a própria "essência atual" da coisa (prop.7). O conatus é a essência atual do corpo e da alma, sua potência natural de autoconservação; é o interesse vital, e o interesse do corpo e da alma é perseverar em ser. A alma, quer tenha idéias inadequadas e confusas, quer tenha idéias adequadas $e$ distintas, é consciente deste esforço (prop.9). Quando referido ao corpo e a alma, esse esforço se chama apetite, quando referido apenas a alma, se chama vontade, conforme comenta Espinosa no escólio desta última proposição, acrescentando ainda que esse esforço...

\footnotetext{
... não é outra coisa senão a essência mesma do homem, de cuja natureza se seguem necessariamente aquelas coisas que servem para sua conservação, coisas que, portanto, o homem está determinado a realizar. Ademais, entre 'apetite' e 'desejo' não há diferença alguma, senão a de que geralmente o 'desejo' se refere aos homens, na medida em que são conscientes de seu apetite e, por isso, pode se definir assim: o desejo é o apetite acompanhado da consciência do mesmo. Assim, pois, fica claro, em virtude de tudo isso, que não intentamos, queremos, apetecemos, nem desejamos algo porque o julgamos bom, mas, pelo contrário, julgamos que algo é bom porque o intentamos, queremos, apetecemos e desejamos. (Spinoza, 1998, p.205-6)
}

E Robinson, reagindo àquela terrível situação, apega-se com fervor a uma idéia (um projeto) que aumente sua potência de agir e de pensar, o que é o mesmo que aumentar seu esforço de perseverar em ser. E põe-se, afinal, a agir e a pensar. Neste instante, em que pensa Robinson? Qual é a primeira coisa que pensa em fazer? - Evadir-se. Robinson pensa em escapar, em fugir, em riscar uma linha de fuga sobre o mar. E começa imediatamente a construir uma embarcação, apressadamente batizada de Evasão. Misturando restos da galeota naufragada com elementos da natureza local, Robinson faz sua primeira e, talvez, mais prodigiosa demonstração de talento técnico polivalente, ao empenhar vários meses e todos os seus esforços e habilidades na construção do Evasão. Mas, pouco a pouco, alguma coisa mal definida começa a se passar com Robinson...

O trabalho foi longo, lento, ao mesmo tempo bruto e minucioso, exigiu intensos esforços físicos e mentais, e só ficou pronto após passar por uma estranha relutância em finalizá-lo. Aproximando-se da conclusão, Robinson 
sente, sobretudo, um grande temor de pôr à prova sua obra e saber se realmente lhe serviria aos seus planos de evasão. Na verdade, ele não apenas teme, mas pressente o fracasso. Aos poucos, vai se dando conta da inevitável perempção de seu projeto: a obra genial aparentemente tropeçara num pequeno detalhe e nascia com a marca de um pecado original que se evidenciava traumaticamente no momento não mais adiável de seu lançamento. "Para dizer a verdade, ele negligenciara completamente o problema do transporte do navio até a beira d'água." Alguma coisa indefinível está acontecendo com Robinson...

Decidiu-se por fim a proceder ao lançamento que obscuros pressentimentos o faziam há tanto tempo adiar. Não o surpreendeu muito a impossibilidade de arrastar pela areia até ao mar aquele casco de peso talvez superior a mil libras. Este primeiro fracasso revelou-lhe, todavia, a gravidade de um problema em que nunca tinha seriamente pensado. Serviu-lhe a ocasião para descobrir um aspecto importante da metamorfose que seu espírito sofria sob a influência da vida solitária. O campo da sua atenção parecia aprofundar-se e, ao mesmo tempo, estreitar-se. Tornava-se-lhe cada vez mais difícil pensar em várias coisas ao mesmo tempo, ou até passar para outro tema de preocupação. Descobriu assim que outrem é para nós um poderoso fator de distração, não apenas porque nos perturba constantemente e nos arranca ao pensamento atual, mas ainda porque a simples possibilidade do seu aparecimento lança um vago luar sobre um universo de objetos situados à margem da nossa atenção mas capaz a todo o momento de se the tornar o centro. Esta presença marginal e como que fantasmal das coisas com que, de imediato, não se preocupava apagara-se aos poucos no espírito de Robinson. Encontrava-se doravante rodeado de objetos submetidos à lei sumária do tudo ou nada, e fora assim que, absorvido na construção do Evasão, perdera de vista o problema de como o lançar à água. (Tournier, 1985, p.31-2)

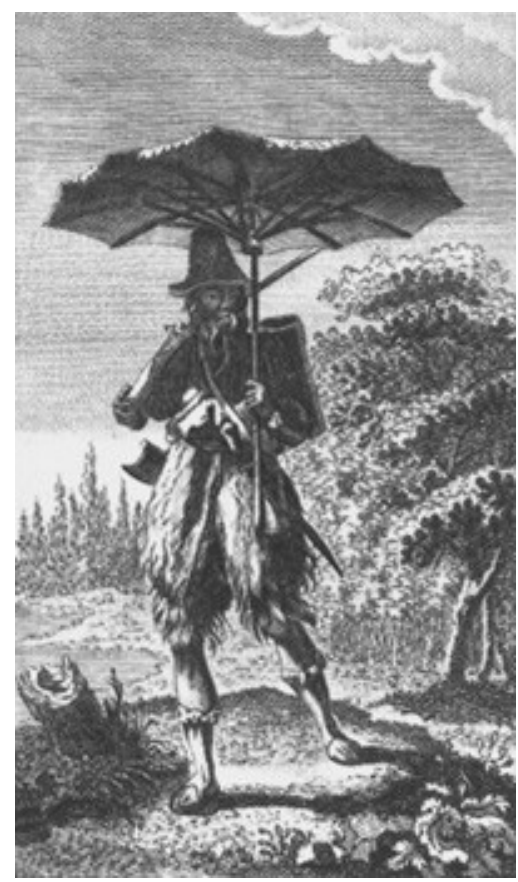

llustração de La vie et les aventures surprenantes de Robinson Crusoé, 1768, chez Laurent Prault, Paris.

\section{Personagem conceitual}

É Robinson, então, o personagem a arrojar-se na cena do pensamento: Robinson Crusoé, aquele cujo destino foi esposar a solidão, aquele que foi, por anos, curtido no seu sol e no seu sal. Em especial, aquele Robinson que nos é apresentado por Michel Tournier em Sexta-Feira ou Os Limbos do Pacífico. Tanto quanto a obra inaugural do escritor inglês Daniel Defoe (As aventuras de Robinson Crusoé, 1719), corresponde ao que Gilles Deleuze (1998) chamou de um "romance experimental indutivo". Contudo, as diferenças entre ambos são determinantes: o Robinson que aqui se convoca não é o crente voluntarioso e empreendedor ou o sobrevivente heróico que reconstrói a "civilização" com os restos de um naufrágio, como em Defoe. Nosso Robinson é, principalmente, o que se viu condenado à solidão e ao "mundo sem outrem" (Deleuze, 1998). Aquele a quem aconteceu participar de um "experimento divino" e não sucumbiu; transformou-se. Sua aventura foi a de perceber-se inteiro transformar até alcançar uma percepção de "si" como um campo de intensidades coincidindo com a própria ilha: Speranza. Não há apenas um encontro com um Sexta-Feira que desembarca mais tarde na ilha, mas uma progressiva metamorfose de Robinson em Sexta-Feira, correspondendo à sua metamorfose em ser solar. Transposto o cabo da solidão, o desejo "decola" dos corpos e o corpo pode, enfim, fazer face ao 
seu duplo ereto, ao seu ser vertical. O desejo faz os corpos deitarem. E pela primeira vez, o corpo está de pé. Nu, desperto, saudável e mestiço.

Por isso o Robinson de Tournier: porque ele não nos fala, em primeiro lugar, da técnica, nem da conquista da América, nem da ética protestante, nem do espírito do capitalismo, mas da Grande Saúde. No romance de Tournier:

O fim, o alvo final de Robinson é a 'desumanização', o encontro da libido com os elementos livres, a descoberta de uma energia cósmica ou de uma grande Saúde elementar, que não pode surgir a não ser na ilha e ainda na medida em que a ilha se tornou aérea e solar. (Deleuze, 1998, p.313)

\section{Os efeitos de Outrem}

O personagem conceitual é Robinson. Sua aventura filosófica: o mundo sem outrem. Suas primeiras meditações: os efeitos de outrem no processo de conhecimento.

Talvez, o mais profundo efeito de outrem no processo de conhecimento seja aquele que Robinson primeiro entreviu no momento do fracasso do lançamento do Evasão: lançar "um vago luar sobre um universo de objetos situados à margem de nossa atenção mas capaz a todo o momento de se lhe tornar o centro." O primeiro efeito de outrem, então, seria a constituição de um "mundo marginal, de um arco, de um fundo que outros objetos, outras idéias podem sair segundo leis de transição que regulam a passagem de uns aos outros" (Deleuze, 1998, p.314). É esse efeito que nos assegura de que não vamos colidir com o mundo a cada desvio do olhar. É desse modo que outrem "povoa o mundo de um rumor benevolente".

E o que ocorre na ausência de outrem?

\footnotetext{
Mundo cru e negro, sem potencialidades nem virtualidades: é a categoria do possível que se desmoronou. (...) Tendo cessado de se estender e se curvar uns em direção aos outros, os objetos se erguem ameaçadores; descobrimos então maldades que não são mais as do homem. Dir-se-ia que cada coisa, tendo abdicado de seu modelo, reduzida a suas linhas mais duras esbofeteia-nos e golpeia-nos pelas costas. A ausência de outrem, nós a sentimos quando damos uma topada, instantes em que nos é revelada a velocidade estupidificante de nossos gestos. (Deleuze 1998, p.314-6)
}

Outrem, portanto, nos "ensina" a sentir a preexistência de um objeto seguinte, de um acontecimento por vir. Há todo um campo de coisas, nesse instante, invisíveis para mim, mas visíveis para outrem, que constitui um campo de virtualidades e de potencialidades capazes, a qualquer momento, de se atualizarem.

Do diário de Robinson:

Em Speranza, há só um ponto de vista, o meu, despojado de qualquer virtualidade. Este despojamento não se fez em um dia. A princípio, por um automatismo inconsciente, eu projetava possíveis observadores parâmetros - no alto das colinas, atrás de um tal rochedo ou nos ramos de uma tal árvore. A ilha encontrava-se, dessa forma, quadriculada por uma rede de interpolações e de extrapolações que a diferenciava e a dotava de inteligibilidade. Assim faz todo o homem normal numa situação normal. Só tomei consciência desta função, como de muitas outras, à medida que ela se degradava em mim. Hoje, é coisa feita. A minha visão da ilha reduz-se a ela 
própria. O que eu não vejo dela é um desconhecido absoluto. Onde quer que eu não esteja neste momento reina uma noite insondável.

(Tournier, 1985, p.47-8)

Apenas pelo acima exposto, fica claro que, para Robinson, a ausência ou a presença de outrem equivale, de fato, a ausência ou a presença de uma dada estrutura do campo perceptivo. Outrem pode ser dito uma estrutura do campo perceptivo. E qual estrutura? A do possível. Outrem é a expressão de um possível $e$, desse modo, estrutura nossas disposições cognitivas de tal forma que o possível - o que pode ser, mas (ainda) não é - faça parte do mundo, seja como simples expressão num rosto, seja ganhando realidade numa fala.

Tomemos um mundo calmo e repousante:

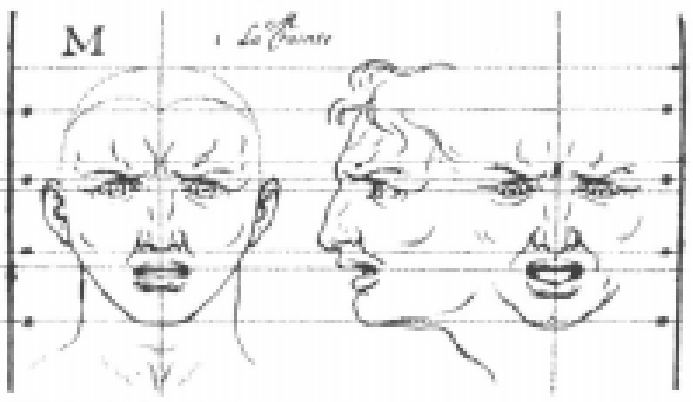

CHARLES LE BRUN, “La crainte” (“O medo”), 1994.
Surge, de repente, um rosto assustado que olha alguma coisa fora do campo. Outrem não aparece aqui como um sujeito, nem como um objeto mas, o que é muito diferente, como um mundo possível, como a possibilidade de um mundo assustador. Esse mundo possível não é real, ou não o é ainda, e todavia não deixa de existir: é um exprimido que só existe em sua expressão, o rosto ou o equivalente do rosto. Outrem é, antes de mais nada, esta existência de um mundo possível. E este mundo possível tem uma realidade própria em si mesmo, enquanto possível: basta que aquele que exprime fale e diga 'tenho medo', para dar uma realidade ao possível enquanto tal (mesmo se suas palavras são mentirosas). (...) Outrem é um mundo possível, tal como existe num rosto que o exprime, e se efetua numa linguagem que lhe dá uma realidade. Neste sentido, é um conceito com três

componentes inseparáveis: mundo possível, rosto existente, linguagem real ou fala. (Deleuze \& Guattari, 1992, p.28-9)

Outrem como estrutura não é, portanto, uma "forma" num campo perceptivo, mas um Outrem a priori, isto é, "a existência do possível em geral", na medida em que existe apenas como expressão num rosto, como expresso em um exprimente que não se parece com ele. Ora, é por definição que o possível só existe enquanto expresso. O possível é o que pode vir a ser, mas não é, ainda não é. Sua única realidade possível é a de ser um expresso. E o que é mais importante: só existe como um expresso num exprimente (rosto, voz), que não se parece com ele. O rosto não imita o que vê, mas expressa. "O semblante terrificado não se parece com a coisa terrificante, ele a implica, a envolve como algo de diferente, numa espécie de torção que põe o expresso no exprimente" (Deleuze, 1998, p.317).

Mas ainda é preciso explicitar um pouco mais de que modo Outrem, enquanto "a existência do possível em geral”, estrutura nossas percepções. Para isso, recorremos, mais uma vez, a uma excelente síntese que nos é oferecida por Deleuze, em parceria com Félix Guattari:

No caso do conceito de Outrem, como expressão de um mundo possível num campo perceptivo, somos levados a considerar de uma nova maneira os componentes deste campo por si mesmo: outrem, não mais sendo um sujeito de campo, nem um objeto no campo, vai ser a 
condição sob a qual se redistribuem, não somente o objeto e o sujeito, mas a figura e o fundo, as margens e o centro, o móvel e o ponto de referência, o transitivo e o substancial, o comprimento e a profundidade... Outrem é sempre percebido como um outro, mas, em seu conceito, ele é a condição de toda percepção, para os outros como para nós. É a condição sob a qual passamos de um mundo a outro. [Outrem e percepção temporal] Outrem faz o mundo passar, e o 'eu' nada designa senão um mundo passado ('eu estava tranqüilo...'). [Outrem e percepção espacial] Por exemplo, Outrem basta para fazer, de todo comprimento, uma profundidade possível no espaço e inversamente, a tal ponto que, se este conceito não funcionasse no campo perceptivo, as transições $e$ as inversões se tornariam incompreensíveis, e não cessaríamos de nos chocar contra as coisas, o possível tendo desaparecido. (Deleuze \& Guattari, 1992, p.30-1)

Ora, os efeitos de Outrem no campo perceptivo, ao condicionarem a percepção espacial e temporal, condicionam simultaneamente a percepção de si (enquanto a consciência de um sujeito separado do objeto), como fica bastante claro neste breve "diálogo" entre Robinson e Deleuze:

O efeito fundamental é a distinção de minha consciência e de seu objeto.

(...) [Outrem e percepção temporal] ... outrem faz com que minha consciência caia necessariamente em um 'eu era', em um passado que não coincide mais com o objeto. Antes que outrem apareça, havia por exemplo um mundo tranqüilizante, do qual não distinguíamos minha consciência; outrem surge, exprimindo a possibilidade de um mundo assustador, que não é desenvolvido sem fazer passar o precedente. [Outrem e percepção de si] Eu nada sou além dos meus objetos passados, meu eu não é feito senão de um mundo passado, precisamente aquele que outrem faz passar. Se outrem é um mundo possível, eu sou um mundo passado. E todo o erro das teorias do conhecimento é o de postular a contemporaneidade do sujeito e do objeto, enquanto que um não se constitui a não ser pelo aniquilamento do outro. (Deleuze, 1998, p.319-20)

\section{Prossigamos com o filósofo selvagem de Speranza:}

E de repente a mola salta. O sujeito arranca-se ao objeto, despojando-o de uma parte da sua cor e do seu peso. Algo estalou no mundo e um pedaço das coisas abate-se, tornando-se eu. Cada objeto é desqualificado em proveito de um sujeito correspondente. A luz torna-se olho, e já não existe como tal: é só excitação da retina. O odor torna-se narina, e o próprio mundo revela-se inodoro. A música do vento nos paletúvios é refutada: mais não é do que perturbação do tímpano. O mundo inteiro acaba por se fundir na minha alma, que é a própria alma de Speranza, arrancada à ilha, a qual morrerá sob meu olhar cético.

Deu-se uma convulsão. Um objeto degradou-se bruscamente em sujeito. Porque sem dúvida o merecia, já que todo mecanismo tem um sentido. Nó de contradições, foco de discórdia, foi eliminado do corpo da ilha, ejetado, repelido. A mola corresponde a um processo de racionalização do mundo. $\mathrm{O}$ mundo busca a sua própria racionalidade e, ao fazê-lo, evacua esse resíduo, o sujeito. (...)

O sujeito é um objeto desqualificado. O meu olho é o cadáver da luz, da cor. O meu nariz é tudo o que resta dos odores quando a sua irrealidade 
fica demonstrada. Mas a minha mão refuta a coisa tida. Logo, o problema do conhecimento nasce de um anacronismo. Implica a simultaneidade do sujeito e do objeto, cujas misteriosas harmonias desejaria iluminar. Ora, o sujeito e o objeto não podem coexistir porque são a mesma coisa, a princípio integrada no mundo real, depois lançada à escória. Robinson é o excremento pessoal de Speranza. Esta fórmula espinhosa enche-me de sombria satisfação. Pois mostra-me a senda estreita e escarpada da salvação, de uma certa salvação pelo menos... (Tournier, 1985, p.87-9)

Como em muitos modelos experimentais, foi pela ausência de um elemento que Robinson descobriu seus efeitos. Antes, era Outrem que governava $e$ organizava as relações transitivas entre os objetos: cada um deles se fechava sobre si ou se abria sobre outros em função dos mundos possíveis expressos por outrem. Depois, quando Outrem desaba, erguem-se as forças elementares (re)instaurando a ordem imanente das coisas.

Em suma: outrem é quem aprisionava os elementos no limite dos corpos e, mais ao longe, nos limites da terra. Pois a própria terra nada mais é do que o grande corpo que retém os elementos. A terra não é terra a não ser povoada de outrem. Outrem é quem fabrica os corpos com os elementos, os objetos com os corpos, assim como fabrica o próprio semblante com os mundos que exprime. O duplo liberado, quando outrem se desmorona, não é, pois, uma réplica das coisas. O duplo, ao contrário, é a imagem endireitada em que os elementos se liberam e se retomam, todos os elementos tornados celestes e formando mil figuras caprichosas elementares... (Deleuze, 1998, p.321-2)

\section{Outrem e o desejo}

Todas essas questões só se tornam plenamente inteligíveis quando levamos em conta uma outra dimensão indissociável do problema do conhecimento. Não apenas as leis da percepção (para a constituição espacial de objetos, para a determinação temporal do sujeito e para o desenvolvimento sucessivo dos mundos) dependem da estrutura Outrem:

Mesmo o desejo, quer seja desejo de objeto ou desejo de outrem, depende da estrutura. Não desejo objeto a não ser como expresso por outrem no modo do possível; não desejo em outrem senão os mundos possíveis que exprime. Outrem aparece como o que organiza os Elementos em Terra, a terra em corpos, os corpos em objetos e que regula e mede ao mesmo tempo o objeto, a percepção e o desejo. (Deleuze 1998, p.327)

Como já vimos, o primeiro momento de Robinson na ilha foi marcado pelo desespero, o mais profundo enfraquecimento do desejo. Deleuze, buscando caracterizar este momento por referência ao funcionamento de uma estrutura Outrem, descreve-o como aquele em que a estrutura ainda funciona, mas já não há mais ninguém para preenchê-la (momento neurótico). Já num momento posterior de sua longa estadia na ilha, Robinson será tomado por um desmesurado ímpeto construtor, que Deleuze interpreta como aquele em que a própria estrutura Outrem começa a se esboroar. O esforço de Robinson, agora, é o de encontrar um substituto para outrem e, desse modo, tentar manter os efeitos da presença de outrem, quando a estrutura já abriu falência (momento psicótico). Robinson constrói a clepsidra (para domesticar o tempo), dedica-se a 
uma produção superabundante (que excede suas necessidades), promulga um código de leis para Speranza e multiplica os títulos e as funções oficiais de uma burocracia absurda.

Essas flutuações e alternâncias de momentos farão com que, durante uma boa parte de sua aventura na ilha, Robinson atravesse uma experiência divergente: por um lado, temos a "civilização" da ilha pelo trabalho; por outro, a "desumanização" do homem pela solidão: à superfície da ilha, Robinson procura continuar a obra "civilizatória", substituindo o dado pelo construído, enquanto a metamorfose provocada pela solidão prossegue levando-o a soluções "cada vez menos semelhantes ao modelo humano". Não tardará para que o filósofo da solidão se pergunte: aonde leva e o que sustenta o ímpeto construtor, quando outrem não é mais uma presença intrínseca do espírito? $\mathrm{O}$ que se passa com o desejo quando "ele nem mesmo sabe com quem se defrontar", quando "desapareceu a montagem de instituições e de mitos que ao desejo permite tomar corpo"? O que experimenta Robinson? A ausência de outrem (em especial, feminino) levou seu desejo a morrer de inanição?

\begin{abstract}
Muito longe disso! Sinto ainda e sempre murmurar dentro de mim essa fonte de vida, mas tornou-se totalmente disponível. Em vez de se conformar docilmente ao leito de antemão preparado pela sociedade, transborda por todos os lados e irradia em forma de estrela, procurando (dir-se-ia às apalpadelas) um caminho, o bom caminho, para onde convergirá e donde deslizará unânime para um objetivo. (Tournier, 1985, p.103-6)
\end{abstract}

O que Robinson está descobrindo é que o desejo sobrevive à morte de seu objeto, assim como ainda descobrirá que, sob certas condições, até se intensifica (Robinson aprenderá a fazer um Corpo sem Órgãos!). Embora seja Outrem que faça o desejo "baixar" sobre os corpos, o desejo não depende, absolutamente, de Outrem para pulsar continuamente no ser. O desejo tem total autonomia em relação a qualquer finalidade exterior. É uma força própria do ser, seu esforço de perseverar em ser, o já mencionado conatus espinosano.

Descobrimos, assim, junto com Robinson, que é falsa a "lei negativa" que relaciona o desejo a uma falta, ou seja: o desejo não é carente daquilo que, transitivamente, deseja. Outro mito igualmente arruinado pela experiência de Robinson é aquele que relaciona o desejo ao prazer por intermédio da "lei da descarga": "o desejo aliviar-se-á no prazer..." Ao experimentar a positividade do "desejo totalmente disponível", ele constata que a equação desejo-prazer só pode muito equivocadamente ser reduzida à "lei da descarga". O que Robinson descobre, outras experiências humanas (filosóficas, religiosas, eróticas, comportamentais...) também permitem descobrir: que o prazer não é de forma alguma o que só poderia ser atingido pela descarga...

... mas o que deve ser postergado ao máximo, porque seu advento interrompe o processo contínuo do desejo positivo. Acontece que existe uma alegria imanente do desejo, como se ele se preenchesse de si mesmo e de suas contemplações, fato que não implica falta alguma, impossibilidade alguma, que não se equipara e que também não se mede pelo prazer, posto que é esta alegria que distribuirá as intensidades de prazer e impedirá que sejam penetradas de angústia, de vergonha, de culpa. (Deleuze \& Guattari, 1996, p.16) 
2 "A Grande Virtude, pornatureza, segue o Caminho, nada além do Caminho" - do capítulo 21 do Tao-tê-king (Laotzeu, 1979, p.61).

${ }^{3}$ No dia 28 de novembro de 1947 , vai ao ar pela Radio France a peça radiofônica de Antonin Artaud Para acabar com o juízo de Deus, na qual o dramaturgo "declara guerra aos órgãos". Deleuze \& Guattari transpõem essa figura estética do Corpo sem Órgãos para o plano de imanência do pensamento, criando-o agora como um conceito filosófico. Não se trata, contudo, do mero empréstimo de uma imagem para "traduzir" uma idéia, mas da importação de todo o esquema de forças que põe em correlação as imagens na composição de Artaud. Tanto que, na mesma transposição, o juízo de Deus também se constitui num conceito: o do próprio organismo ou da "operação Daquele que faz um organismo" sobre o CsO: "O CsO grita: fizeram-me um organismo! dobraramme indevidamente! roubaram meu corpo! o juízo de Deus arranca-o de sua imanência, e lhe constrói um organismo, uma significação, um sujeito. É ele o estratificado. Assim, ele oscila entre dois pólos: de um lado, as superfícies de estratificação sobre as quais ele é rebaixado e submetido ao juízo, $e$, por outro lado, o plano de consistência no qual ele se desenrola e se abreà

experimentação." (Deleuze \& Guattari, 1996, p.21)
Trata-se, então, de saber estabilizar as "intensidades de prazer" num platô, $e$ não apenas do prazer de descarregar as intensidades. E é por isso que, uma vez concluída a "desumanização" de Robinson, a descrição de sua sexualidade mais pareceria saída de um tratado chinês de taoísmo, como indicação do caminho para se alcançar a circulação das intensidades (yin e yang) e o aumento das potências:

A condição desta circulação e desta multiplicação é que o homem não ejacule. Não se trata de sentir o desejo como falta interior, nem de retardar o prazer para produzir um tipo de mais-valia exteriorizável, mas, ao contrário, de construir um corpo sem órgãos intensivo, Tao, um campo de imanência onde nada falta ao desejo e que, assim, não mais se relaciona com critério algum exterior ou transcendente. É verdade que todo circuito pode ser rebaixado para fins de procriação (ejacular no bom momento das energias); e é assim que o confucionismo o entende. Mas isto é verdade apenas para uma face deste agenciamento de desejo, a face voltada em direção aos estratos, organismos, Estado, família... Não é verdade para a outra face, a face Tao de desestratificação que traça um plano de consistência próprio ao desejo ele mesmo. (Deleuze \& Guattari, 1996, p.19)

\section{O plano de imanência do desejo é o Corpo sem Órgãos}

O aumento das potências, como aprendemos com Espinosa, é o mesmo que o fortalecimento do conatus e, também, um dos principais componentes do conceito de Grande Saúde aqui proposto. Outro forte componente deste conceito - tanto mais por ser aquele que lhe confere seus conteúdos de felicidade prazenteira (indissociável de qualquer idéia de Saúde que se preze) -, está relacionado ao que acima foi chamado de uma "alegria imanente do desejo", que está, por sua vez, relacionada à possibilidade de uma "estranha estabilização intensiva": a constituição de um platô de intensidades.

"Estranha", pelo menos, ao "espírito ocidental"...

Gregory Bateson serve-se da palavra 'platô' para designar algo muito especial: uma região contínua de intensidades, vibrando sobre ela mesma, e que se desenvolve evitando toda orientação sobre um ponto culminante ou em direção a uma finalidade exterior. Bateson cita como exemplo a cultura balinense, onde jogos sexuais mãe-filho, ou bem querelas entre homens, passam por uma estranha estabilização intensiva. 'Um tipo de platô contínuo de intensidade substitui o orgasmo', a guerra ou um ponto culminante. É um traço deplorável do espírito ocidental referir as expressões e as ações a fins exteriores ou transcendentes em lugar de considerá-los num plano de imanência segundo seu valor em si. (Deleuze \& Guattari, 1995a, p.33)

A Grande Saúde é o Tao: "campo de imanência onde nada falta ao desejo". O Tao é o Caminho, o bom caminho para o desejo - e o bom caminho é a $V_{i r t u d e}$ (nas palavras de Robinson: o desejo tornado "totalmente disponível" procurará "um caminho, o bom caminho, para onde convergirá e donde deslizará unânime para um objetivo"). E o caminho para a Grande Saúde passa por "construir um corpo sem órgãos intensivo". É preciso, como Robinson, saber fazer o que Deleuze \& Guattari (1996) chamam de um Corpo sem Órgãos $(\mathrm{CsO})^{3}$, o que é sempre muito arriscado... 
Não foi, entretanto, por meio de práticas taoístas que Robinson conseguiu criar para si um $\mathrm{CsO}$, mas conseguindo atravessar a experiência radical de um mundo sem outrem, que lhe foi imposta pelo destino. Experiências como a de Robinson, assim como qualquer outro meio de se fazer um $\mathrm{CsO}$, são sempre aventuras de grande risco. É mesmo o Grande Risco: cotejar o caos. O verdadeiro caminho para a Grande Saúde passa sempre pelo Grande Risco ${ }^{4}$. E é somente por esse motivo - por envolver o Grande Risco - que o mundo sem Outrem pode eventualmente conduzir à Grande Saúde.

Como já vimos, Outrem é quem organiza a profundidade, pacifica-a, tornando-a possível de ser vivida. O mundo sem Outrem é o retorno agressivo do sem-fundo, é a perda de todo sentido e, em vários sentidos, a morte... A não ser que Robinson aprenda a viver numa nova dimensão ou invente um outro sentido para a perda de Outrem, o que poderia ser o mesmo que encontrar a Grande Saúde. A experiência de Robinson nos ensina que o caminho até o desabamento completo da estrutura Outrem passa por uma sucessão de momentos que, numa alternativa de desfecho trágico, poderia ser descrita como a sucessão neurose-psicose-morte. Mas Robinson é aquele que encontrou uma outra alternativa para a perda de Outrem: criar para si um CsO.

E o que é um $\mathrm{CsO}$ ?

De todo modo você tem um (ou vários), não porque ele pré-exista ou seja dado inteiramente feito - se bem que sob certos aspectos ele préexista - mas de todo modo você faz um, não pode desejar sem fazê-lo... É sobre ele que dormimos, velamos, que lutamos, lutamos e somos vencidos, que procuramos nosso lugar, que descobrimos nossas felicidades inauditas e nossas quedas fabulosas, que penetramos e somos penetrados, que amamos...

Onde a psicanálise diz: Pare, reencontre seu eu, seria preciso dizer: vamos mais longe, não encontramos ainda nosso $\mathrm{CsO}$, não desfizemos ainda suficientemente nosso eu. Substituir a anamnese pelo esquecimento, a interpretação pela experimentação. Encontre seu corpo sem órgãos, saiba fazê-lo, é uma questão de vida ou de morte, de juventude e de velhice, de tristeza e de alegria. É aí que tudo se decide... $\mathrm{O} \mathrm{CsO}$ é o que resta quando tudo foi retirado. E o que se retira é justamente o fantasma, o conjunto de significâncias e subjetivações... Um $\mathrm{CsO}$ é feito de tal maneira que ele só pode ser ocupado, povoado por intensidades. Somente as intensidades passam e circulam. Mas o CsO não é uma cena, um lugar, nem mesmo um suporte onde aconteceria algo. Nada a ver com um fantasma, nada a interpretar. O CsO faz passar intensidades, ele as produz $e$ as distribui num spatium ele mesmo intensivo, não extenso. (Deleuze \& Guattari, 1996, p.9-13)

Mas tudo isso é muito arriscado e é realmente preciso muita prudência para se fazer um $\mathrm{CsO}$. A rigor, jamais se chega completamente a um $\mathrm{CsO}$, pois ele é um limite. É preciso saber disso para se ter alguma chance de saber fazê-lo: o CsO deve ser uma desterritorialização relativa; para fazê-lo é preciso "ter sempre um pedaço de nova terra":

Liberem-no com um gesto demasiado violento, façam saltar os estratos sem prudência e vocês mesmos se matarão, encravados num buraco
${ }^{4}$ Essa idéia é bastante próxima da idéia nietzscheana de saúde como aquilo que nos faz "viver através das doenças do vivido". Isso explica porque a Grande Saúde pode nos dar, às vezes, a impressão de uma saúde frágil, abalada. Aqueles que experimentaram fazer o Corpo sem Órgãos podem ter a aparência de um Robinson-solar, de um santo ou de um artista: "Desse ponto de vista, os artistas são como os filósofos, têm freqüentemente uma saudezinha frágil, mas não por causa de suas doenças nem de suas neuroses, é porque eles viram na vida algo de grande demais para qualquer um, de grande demais para eles, e que pôs neles a marca discreta da morte. Mas esse algo é também a fonte e o fôlego que os fazem viver através das doenças do vivido (o que Nietzsche chama de saúde). 'Um dia saberemos talvez que não havia arte, mas somente medicina..." (Deleuze \& Guattari, 1992, p.224). 
negro, ou mesmo envolvidos numa catástrofe, ao invés de traçar o plano. $\mathrm{O}$ pior não é permanecer estratificado - organizado, significado, sujeitado mas precipitar os estratos numa queda suicida ou demente, que os faz recair sobre nós, mais pesados do que nunca. Eis então o que seria necessário fazer: instalar-se sobre um estrato, experimentar as oportunidades que ele nos oferece, buscar aí um lugar favorável, eventuais movimentos de desterritorialização, linhas de fuga possíveis, vivenciá-las, assegurar aqui e ali conjunções de fluxos, experimentar segmento por segmento dos contínuos de intensidades, ter sempre um pedaço de nova terra... É somente aí que o $\mathrm{CsO}$ se revela pelo que é, conexão de desejos, conjunção de fluxos, continuum de intensidades. (...) Porque o CsO é tudo isto: necessariamente um Lugar, necessariamente um Plano, necessariamente um Coletivo (agenciando elementos, coisas, vegetais, animais, utensílios, homens, potências, fragmentos de tudo isto, porque não existe 'meu' corpo sem órgãos, mas 'eu' sobre ele, o que resta de mim, inalterável e cambiante de forma transpondo limiares). (Deleuze \& Guattari, 1996, p.24-5)

\section{Espinosa e a dupla-articulação}

Para Espinosa, há uma única e mesma substância constituindo o universo inteiro e ela é eterna porque, nela, ser, existir e agir (essência, existência e potência) são uma só e mesma coisa. A substância é causa sui (causa de si mesma), "aquilo cuja essência implica a existência, aquilo cuja natureza só pode conceber-se como existente" (primeira definição do livro 1, "De Deus").

Contudo, se por um lado, no "monismo" espinosano a substância é tudo que é, por outro, vemos se expressar em seu pensamento, logo no primeiro axioma do livro 1, uma dupla-articulação: "Tudo que é, ou é em si, ou é em outra coisa." Isto é, ou existe em si e por si (é substância), ou existe em outro e por outro. A esse segundo tipo de existência (e conhecimento), Espinosa denominará modos da substância. Ou ainda, segundo sua própria definição (a quinta do livro 1): "Por modo entendo as afecções de uma substância. Ou seja, aquilo que é em outra coisa, por meio da qual também é conhecido."

A substância é aquela que é em si e não precisa, para formar-se enquanto conceito, do conceito de outra coisa e atributo é "aquilo que o entendimento percebe de uma substância como constitutivo da mesma" (quarta definição). Dos infinitos atributos de Deus (da substância), nós conhecemos, "verdadeira e adequadamente", apenas dois: a extensão e o pensamento. A atividade do atributo extensão dá origem aos corpos, como modos finitos da extensão, assim como a atividade do atributo pensamento dá origem às idéias e às almas (mens), como modos finitos do pensamento.

Deleuze \& Guattari se perguntam: "o grande livro sobre o CsO não seria a Ética?"

Os atributos são os tipos ou os gêneros de $\mathrm{CsO}$, substâncias, potências, intensidades Zero como matrizes produtivas. Os modos são tudo o que se passa: as ondas e as vibrações, as migrações, limiares e gradientes, as intensidades produzidas sob tal ou qual tipo substancial a partir de tal matriz.... O problema de uma mesma substância para todas as substâncias, de uma substância única para todos os atributos, vem a ser este: existe um conjunto de todos os CsO? Mas se o $\mathrm{CsO}$ já é um limite, o que seria necessário dizer do conjunto de todos os $\mathrm{CsO}$ ? O problema não é mais aquele do Uno e do Múltiplo, mas o da multiplicidade de fusão, que 


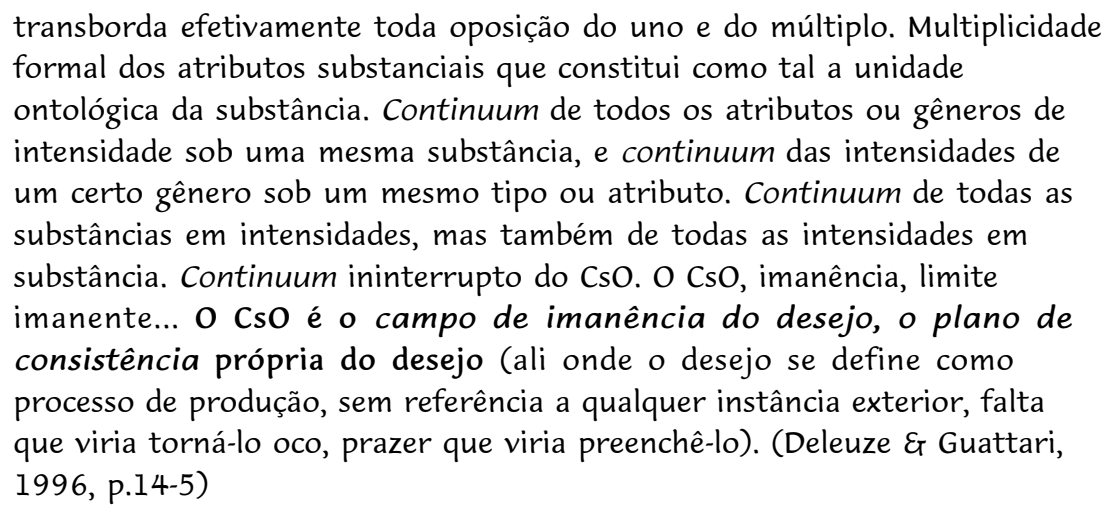

O desejo é uma superfície de emissão de singularidades e essa superfície funciona - no caso da Ética de Espinosa - como uma espécie de interestrato do corpo e da alma, a desestratificação de permeio que faz a articulação, a superfície com uma face para cada estrato e, a partir da qual, ambos os estratos se formam: dupla-articulação.

Cabe dizer que os elementos de um estrato não pré-existem à duplaarticulação, pois é ela que os distribui segundo seu traçado em cada estrato. E é por isso que os elementos de cada estrato - do corpo e da alma, no caso da Ética - estão reciprocamente pressupostos. Segundo a proposição 7 do livro 2 ("Da natureza e origem da alma"): "A ordem e a conexão das idéias são as mesmas que a ordem e a conexão das coisas." Entre os elementos da alma e os elementos do corpo, as relações são biunívocas: há isomorfismo com pressuposição recíproca (identidade de "ordem"). A alma e o corpo são isonômicos: expressam as mesmas leis e os mesmos princípios (identidade de "conexão", cf. Deleuze, 2002, p.74 ss.). Para Espinosa, isso se dá porque alma e corpo constituem um único e mesmo indivíduo, assim como a substância pensante e a substância extensa são uma única e mesma substância, cada qual apreendida desde seu atributo. A alma sabe imediatamente do corpo, sem que esse saber se modifique ao saber-se "separada" do corpo. "Separá-la" do corpo é, para Espinosa, só um modo de tratá-la em abstrato, enquanto ela segue, de fato, inextricavelmente acoplada ao funcionamento do corpo.

Essa dupla-articulação inscreve-se no coração do pensamento de Espinosa (expressando-se nos estratos humanos, em sua Ética). Corresponde ao que vários intérpretes chamam de sua "ontologia bimembre" - uma ontologia geral (da substância) e uma ontologia específica (dos modos) -, mas também a sua particular doutrina do "paralelismo": por um lado, a irredutibilidade da alma ao corpo; por outro, o reconhecimento que a alma só segue pelos caminhos do corpo. Por um lado, distinção real entre os estratos; por outro, o reconhecimento que um estrato só se desenvolve a partir de um outro estrato, que lhe serve de subestrato.

Para Deleuze, é "na esteira dos estóicos" que Espinosa leva essa duplaarticulação até o fim, fendendo "a causalidade em duas cadeias bem distintas: os efeitos entre si, sob a condição de que as causas, por seu turno, sejam apreendidas entre si. Os efeitos remetem aos efeitos, assim como os signos remetem aos signos: conseqüências separadas de suas premissas" (Deleuze, 1997, p.159). Ou seja, os efeitos são irredutíveis a suas causas, mas são assim mesmo efeitos.

Para que fique mais clara toda a singularidade desta dupla-articulação, ainda precisamos adentrar um pouco mais a vertiginosa filosofia de Espinosa $e$ 
${ }^{5}$ Espinosa discute destacadamente esta solução de Descartes no prefácio do livro 5 ("Do poder do entendimento ou da liberdade humana"), onde demarca com nitidez suas diferenças de concepção. Deixa claro, por exemplo, como sua noção de alma (mens) se distingue da anima cartesiana, que seria ainda um princípio "espiritual" e cujo funcionamento, por isso, seria inexplicável, exceto se imaginarmos, como Descartes, que a alma viria a saber dos movimentos do corpo por meio desta pequena "glândula suspensa no meio do cérebro, de tal modo que possa ser movida pelo menor movimento dos espíritos animais..." (Spinoza, 1998, p.384)

${ }^{6}$ Livro 2: Proposição 19: "A alma humana não conhece o corpo humano propriamente, nem sabe que este existe, a não ser pelas idéias das afecções de que o corpo é afetado." $A$ alma só percebe o corpo como existente em ato.

Proposição 22: “A alma humana percebe não só as afecções do corpo, mas também as idéias dessas afecções." Proposição 23: "A alma não conhece a si mesma, senão enquanto percebe as idéias das afecções do corpo." conhecer minimamente o que poderíamos chamar de...

\section{Afectologia espinosana}

Para Espinosa, a alma é a idéia do corpo e, num sentido muito geral, o corpo é o objeto da alma. Conforme a proposição 13 do livro 2: "O objeto da idéia que constitui a alma humana é um corpo, ou seja, certo modo da Extensão existente em ato, e não outra coisa". Esta é uma das mais célebres proposições de sua Ética, sobretudo pelo escólio em que Espinosa não apenas afirma a união alma-corpo (na contramão de Descartes), mas expõe o que entende por esta união. Não existe propriamente um problema da ligação alma-corpo para Espinosa (como existe para Descartes, que situou esta ligação na glândula pineal ${ }^{5}$ ), porque alma e corpo não estão realmente separados (apenas mentalmente, isto é, só enquanto uma idéia na alma e que é uma idéia da alma), porque é da essência da alma, por ser atividade pensante, estar ligada ao seu objeto de pensamento, de estar ligada à vida de seu objeto, o corpo.

A alma é consciência da vida de seu corpo e, igualmente, consciência de ser consciente disto. Mais exatamente, a alma é consciência das afecções do corpo, bem como das idéias que a alma se faz dessas afecções (os afectos) ${ }^{6}$. Idéia do corpo e idéia da idéia do corpo. Idéia do corpo, idéia da alma. Consciência do corpo, consciência de si. A alma só tem consciência de si por meio da consciência das modificações que se dão na vida do corpo. Uma afecção é um estado do corpo, num determinado momento, sob o efeito de um mundo. Mas... surge outrem com um rosto assustado, fazendo o mundo passar ("eu estava tranqüilo..."), e já estamos num outro "estado de afecção". Graças a outrem, passamos sem cessar de um estado a outro $e$, nessas passagens, experimentamos "potências aumentativas" e/ou "servidões diminutivas"...

\footnotetext{
Não é que comparamos os dois estados numa operação reflexiva, mas cada estado de afecção determina uma passagem para um 'mais' ou para um 'menos'... A afecção, pois, não só é o efeito instantâneo de um corpo sobre o meu mas tem também um efeito sobre minha própria duração, prazer ou dor, alegria ou tristeza. São passagens, devires, ascensões e quedas, variações contínuas de potência que vão de um estado a outro: serão chamados afectos, para falar com propriedade, e não mais afecções. (Deleuze, 1997, p.157)
}

A alma é consciência do corpo na medida em que é consciente de suas afecções, consciente dos "estados do corpo": dos efeitos de um corpo sobre outro no espaço. A alma é consciência da alma na medida em que é consciente de seus afectos, de suas "variações de potência": dos efeitos de uma afecção sobre uma duração.

Em síntese, a alma é consciência dos diferentes "estados do corpo" (affectio) e de suas "variações de potência" (affectus). Esse é seu nível mais elementar de conhecimento: a pura consciência desses estados (efeitos sobre o corpo) e dessas variações (efeitos sobre sua duração), que o corpo exprime como imagens ou signos.

Deleuze (1997), num indispensável ensaio sobre as três "Éticas" de Espinosa, oferece-nos o que se poderia chamar das linhas gerais de uma "semiótica" espinosana: uma "teoria espinosana do signo" (sua ética dos signos) que complementaria eficazmente o conhecimento aqui iniciado de 
sua "afectologia". Antes, porém, é preciso, uma vez mais, para todas essas questões, insistir na inseparabilidade do desejo, bem como compreender um pouco melhor de que modo Espinosa vê o corpo e sua força imaginante.

\section{Fisiologia do Corpo sem Órgãos}

A alma é força pensante e Espinosa chama de entendimento a potência interna da alma para pensar. Em seu imanentismo, ele identifica essência (ser) e potência (agir segundo uma causalidade interna) e, por isso, para Espinosa, a essência da alma é sua potência interna para pensar. Isso, contudo, não significa uma concepção puramente "intelectualista" da alma, pois, como já vimos, o filósofo também afirma que a essência atual da alma (e do corpo) é o conatus, ou seja, o apetite/desejo. A essência da alma (e do corpo) é o desejo, o que é o mesmo que sua potência interna de pensar (e agir). O desejo (entendido como a expressão propriamente humana do apetite, sendo este, a expressão propriamente animal do "interesse vital", do "esforço de autoconservação" que anima cada ser) é a essência do homem, sua potência interna de autodeterminar-se.

Em sua estratificação "anímica" ou "mental", o desejo é força pensante e Espinosa chama de vontade esse desejo que é puro pensamento. É por ser desejo (esforço vitalmente interessado) que, a alma, as coisas apetecem ou aborrecem. Querer é a afirmação ou a negação de uma idéia segundo as determinações do desejo. Pensar é conhecer alguma coisa afirmando ou negando sua idéia (cf. Chauí, 1995, p.57 ss.). É desse modo que podemos entender a importante proposição 49 do livro 2: "Na alma não se dá nenhuma volição, no sentido de afirmação e negação, aparte aquela que está implícita na idéia enquanto idéia". E, no corolário, não deixa dúvidas: "A vontade e o entendimento são um e o mesmo."

Já em sua estratificação "somática" ou "corporal", o desejo é força imaginante e Espinosa chama de signo esse desejo que é pura imagem ${ }^{7}$. Mas, como o desejo chega a ser imagem? Ou, mais exatamente, de que modo o desejo faz imagens? Para podermos compreender com clareza de que modo o desejo, de fato, participa da formação das imagens, seria ideal conhecer a completa visão espinosana do corpo, seria preciso retomar todos seus postulados sobre o corpo, que encontramos no livro 2, e mais as proposições que se seguem (14-30), que compõem a sua singular "fisiologia" - uma fisiologia do Corpo sem Órgãos! Contudo, para não nos desviarmos de nosso percurso principal, retomemos apenas alguns postulados:

I. O corpo humano se compõe de muitíssimos indivíduos (de diversa natureza), cada um dos quais é mui composto.

II. Alguns dos indivíduos que compõe o corpo humano são fluidos; outros são moles e outros, enfim, são duros.

III. Os indivíduos que compõem o corpo humano (e, por conseguinte, o próprio corpo humano) são afetados de muitíssimas maneiras pelos corpos exteriores.

IV. O corpo humano necessita para conservar-se, de muitíssimos outros corpos, e é como se esses o regenerassem continuamente.

V. Quando uma parte fluida do corpo humano é determinada por um corpo externo a se chocar freqüentemente com outra parte mole, altera a superfície desta e lhe imprime uma espécie de vestígio do corpo externo que a afeta. (Spinoza, 1998, p.137)

\footnotetext{
${ }^{7}$ Se pensarmos o corpo como "organismo", tenderemos a situar a formação destas imagens no cérebro. Contudo, é mais propriamente no $\mathrm{CsO}$ que estas imagens se formam; $e$ é assim, antes de mais nada, que estão relacionadas ao desejo: são "figuras" intensivas que se recortam sobre o plano de imanência do desejo.
} 
${ }^{8}$ Como se sabe, toda patologia produz uma semiótica própria, que não deixa de ser uma "atividade" própria ao padecimento, a doença "em ato". Basta lembrar, por exemplo, de toda a semiótica da fácies: a doença como expressão num rosto. $A$ propósito, observemos também como o termo fácies apresenta um curioso desdobramento semântico: "Med. Modificação de aspecto imprimida à face por

certos estados mórbidos... Anat. Superfície específica de uma estrutura ou de um órgão do corpo humano... Geol. Conjunto dos caracteres de uma rocha, considerados sob o aspecto de sua formação". Superfície de expressão, superfície de estratificação... Facies totius Naturae.

9 “... mas a força não é o que age, é, como sabiam Leibniz e

Nietzsche, o que percebee experimenta." (Deleuze \& Guattari, 1992, p.169).

${ }^{10}$ Livro 2: Proposição 25: "A idéia de uma afecção qualquer do corpo humano não implica o conhecimento adequado do corpo exterior."

Proposição 26: "A alma humana não percebe nenhum corpo exterior como existente em ato senão através das idéias das afecções de seu próprio corpo."
Esse "vestígio" de um corpo sobre outro, ou ainda, esse "estado de um corpo que tenha sofrido a ação de um outro corpo: é uma affectio" (Deleuze, 1997; p.156). Uma afecção: um efeito; o efeito de um corpo sobre outro. É esse efeito, causado pelos corpos externos sobre o corpo humano, que Espinosa chama de imagem ou signo. É assim que o corpo "imagina": como uma passividade "ativa", como pathos ${ }^{8}$, paixão. A imagem é uma paixão.

Notemos, que, por ser desejo, a alma se faz idéias inteiramente "interessadas" das afecções corporais, do mesmo modo que estas já são, por sua vez, "estados do corpo", paixões, passividades, mas passividades "ativas", porque inteiramente vetorializadas, imantadas pelo "interesse vital" 9 . Nossas imagens das coisas que nos afetam - tomadas num sentido mais estritamente cognitivo de uma percepção ou sensação -, dependem, antes de mais nada, do modo como estas coisas afetam nosso conatus: nosso desejo, nosso esforço de perseverar em ser e nossa potência de agir e pensar. Como já foi dito, cada nova imagem, na medida em que corresponde à instalação de um outro "estado do corpo", é também necessariamente a percepção/ sensação de uma variação de potência em relação ao estado anterior: um aumento ou uma diminuição da força do conatus. As imagens ou signos são sempre efeitos: seja em termos de afecção das "partes fluidas e moles" do corpo por outros corpos, seja em termos de afecção da duração do corpo por vetores de crescimento e/ou diminuição do desejo.

Notemos também que as idéias, por serem idéias das afecções ou estados do corpo, não têm como referente direto um objeto ou uma causa externa (por exemplo, um mundo assustador), mas seu efeito no corpo humano, que é a própria imagem ou signo (talvez, um rosto assustado) ${ }^{10}$. Por isso, um signo, mesmo meramente indicativo, nunca se parece com a coisa, mas corresponde a seu efeito no corpo, do mesmo modo que um rosto assustado, como já dissemos, não tem qualquer semelhança com o mundo assustador que exprime. Ainda uma vez, o que temos, é a dupla-articulação: um signo só remete a outro signo, e não à coisa, ainda que seja um efeito dessa coisa.

Mas, para que possamos entender de que modo um signo remete a outro, é preciso conhecer um outro aspecto fundamental da fisiologia espinosana do corpo: para produzir uma imagem, o corpo deve ser imaginante, mas para que uma imagem envie a outra, é preciso que o corpo também seja, como diz Chauí (1995), memorioso. Vejamos a interessante proposição 17:

"Se o corpo humano experimenta alguma afecção que implica a natureza de algum corpo exterior, a alma humana considerará dito corpo exterior como existente em ato, ou como algo que lhe está presente, até que o corpo experimente uma afecção que exclua a existência ou presença desse corpo.

Escólio: ... servindo-nos de termos usuais, chamaremos 'imagens' das coisas, as afecções do corpo humano, cujas idéias nos representam os corpos exteriores como se nos estivessem presentes, ainda que não reproduzam a figura das coisas. E quando a alma considerar as coisas desta maneira, diremos que os 'imagina'. E, nesse ponto, para começar a indicar o que é o erro, quisera notásseis que as imaginações da alma, em si mesmas consideradas, não contêm erro algum; ou seja, a alma não erra pelo fato de imaginar, mas apenas na medida em que se encontra carente de uma idéia que exclua a existência daquelas coisas que imagina estar-lhe presente. Pois se a alma, ao mesmo tempo em que imagina como presentes coisas que não existem, soubesse que realmente não existem, 
atribuiria sem dúvida essa potência imaginativa a uma virtude, e não a um vício de sua natureza; sobretudo, se essa faculdade de imaginar dependesse de sua única natureza, isto é, se essa faculdade de imaginar que a alma possui fosse livre. (Spinoza, 1998, p.139-42)

O corpo imagina; a alma imagina. Enquanto é o corpo que imagina, a imagem, enquanto efeito, não se encontra totalmente separada de sua causa, ou seja, num certo sentido, o corpo só imagina enquanto a causa da imagem se encontra presente. Quando é a alma que imagina, a imagem pode se fazer presente mesmo quando sua causa está ausente, porque a alma tem a potência de reconsiderá-la segundo a espécie das idéias: as idéias das afecções. Espinosa chama de signo essa "idéia de um efeito captado em condições que o separam de suas causas" (Deleuze, 2002, p.111). É interessante notar como, no escólio acima, Espinosa ressalta o risco implícito nessa faculdade imaginativa da alma: está tanto na origem de vícios, quanto de virtudes. Ao realizar-se como imaginação (imaginando os objetos ausentes) e, nesse sentido, podendo tomar as imagens de forma inteiramente desligada de suas causas (um efeito só remetendo a outro efeito, um signo, a outro signo), a alma se presta à fabricação de causas imaginárias: as “idéias imaginativas". Para Espinosa, um conhecimento é falso, sempre que a alma excluir a idéia de que estejam, de fato, ausentes, as coisas que imagina como se estivessem presentes $e$, com isso, pretender que as relações causais estabelecidas entre as imagens correspondam a relações causais entre as coisas. Contudo, se o corpo só é capaz de imaginar (pois não é de sua natureza pensar), a alma pode, além de imaginar, também ter acesso ao verdadeiro, graças a sua potência própria, o poder de pensar, quando toma a iniciativa do conhecimento e faz de sua potência imaginativa uma virtude, porque a faz depender de sua única natureza, a faz uma potência livre. Nesse sentido, o pensamento poderia ser definido como uma potência imaginativa livre.

A grande questão, a partir daí, é como passamos da imagem ou signo, como efeito "necessário" de uma causalidade externa, para o pensamento como causa "livre" e interna. Não será do mesmo modo que passamos do corpo ao signo, que passaremos do signo ao pensamento: através do desejo? Uma vez que é o signo que se encontra no centro deste movimento, passemos à acima mencionada "semiótica" espinosana sistematizada por Deleuze, que deve complementar o conhecimento de sua "afectologia".

\section{Semiótica espinosana}

As relações de movimento e repouso, de rapidez e lentidão, entre as partes fluidas e moles, em seus contatos com outros corpos, gravam em nosso corpo todos os "vestígios" destas relações (sombras das coisas em nós) e a vida de um corpo é a variação contínua de sua potência como decorrência dessa sucessão de afecções (muitas, simultâneas) que experimenta. Pois o corpo, além de imaginante, é memorioso, e faz com que nossa alma seja capaz de "presentificar" imagens de coisas que não estão mais presentes - quando outrem já fez o mundo passar! - e com elas re-presentar o tempo, isto é, seqüências associativas e generalizadoras de imagens instantâneas gravadas em nossa carne: "idéias imaginativas", conhecimento inadequado (cf. Chauí, 1995; p.61 ss.).

As afecções do corpo (as imagens) são sempre variações de potência (os afectos), não são efeitos desinteressados, mas modificações da vida do corpo $e$ do sentido "psíquico" dessa vida corporal, fundadas no interesse vital que, do 
${ }^{11}$ Certamente, por analogia com a noção de escala na Física: "seqüência ordenada de marcas (traços, pontos etc.) mediante a qual se estabelece, num instrumento de medida, a

correspondência entre a sua resposta e a grandeza que ele mede."

12 Livro 2: Proposição 16: "A idéia da afecção, qualquer que seja, em virtude da qual o corpo humano é afetado pelos corpos exteriores, deve implicar a natureza do corpo humano e, ao mesmo tempo, a do corpo exterior." Corolário I: "A alma humana percebe junto com a natureza de seu próprio corpo, a de muitíssimos outros." Corolário II: "As idéias que temos dos corpos exteriores revelam muito mais da constituição de nosso próprio corpo, do que a natureza dos corpos exteriores."

${ }^{13}$ É a própria noção de "eminência", tão reprovada por Espinosa. Conforme coloca no vertiginoso apêndice do livro 1: "Todos os preconceitos que procuro indicar aqui dependem de um só: o fato de que os homens suponham comumente que todas as coisas da natureza atuam, de modo igual a eles mesmos, em razão de um fime inclusive têm certo que mesmo Deus dirige todas as coisas na direção de uma certa finalidade, pois dizem que Deus fez todas as coisas com vistas ao homeme criou o homem para que lhe renda culto." (Spinoza, 1998, p.96) lado do corpo, o faz mover-se (afetar e ser afetado por outros corpos) e, do lado da alma, a faz pensar (cf. Chauí, 1995, p.63). É por isso que Espinosa diz que a alma é atividade pensante que se realiza como vontade, isto é, segundo as determinações do desejo. O pensamento está fundado no interesse vital $e$, por isso, há uma volição implícita em cada idéia. Porém, para Espinosa, pensar, propriamente, pressupõe que a alma seja a "causa livre" de suas idéias. Na medida em que é vontade, o pensamento não pode ser dito "causa livre", mas apenas "causa necessária" (cf. prop. 32 do livro 1). Não há, entretanto, uma oposição real entre estas duas exigências causais, pois, como se verá mais adiante, o pensamento, para Espinosa, poderia ser definido como uma operação "interessada" sobre formas, capaz de estabelecer um "feliz" compromisso entre o "livre" e o "necessário".

O pensamento enquanto imaginação procede, mais geralmente, segundo uma relação formal: identidade de "ordem e conexão", correspondência modal. $\mathrm{O}$ pensamento enquanto vontade procede, mais geralmente, segundo uma relação binária: mais-menos, afirmação-negação etc.. O pensamento enquanto imaginação lida com aquilo que Deleuze (1997) chama de "signos escalares"1" (as afecções ou estados de corpo), cujo livro principal é o segundo da Ética, "Da natureza e origem da alma". O pensamento enquanto vontade lida com aquilo que Deleuze chama de "signos vetoriais" (os afectos ou variações de potência), cujo livro principal é o terceiro, "Da origem e natureza dos afectos".

Segundo a leitura extremamente fina que faz da obra de Espinosa, haveria, para Deleuze, quatro tipos principais de signos escalares:

Os primeiros - os elementos mais simples - seriam os "efeitos físicos sensoriais ou perceptivos": os signos indicativos que, na singular visão de Espinosa, indicariam, em primeiro lugar, a natureza de nosso próprio corpo (seus estados) e, apenas secundariamente, os corpos exteriores ${ }^{12}$. Deleuze os chama de índices sensiveis.

Mas, como nossa natureza é finita, a alma "retém daquilo que a afeta somente tal ou qual característica selecionada (o homem animal vertical, ou racional, ou que ri)", fazendo-se, assim, idéias de nossas afecções que são, a rigor, signos abstrativos. Deleuze os chama de ícones lógicos.

A imaginação continua, entretanto, seu trabalho pela via da antropomorfização13: "sendo o signo sempre um efeito, tomamos o efeito por um fim... (visto que o sol esquenta, acreditamos que ele é feito 'para' nos esquentar...)." Os efeitos tomados por fins são, afinal de contas, efeitos morais. E o que temos, agora, são signos imperativos: "Põe-te ao sol!" Rende culto a Deus! Deleuze chama esses signos de símbolos morais.

Por fim, a imaginação produz signos que são propriamente "efeitos imaginários: nossas sensações e percepções nos fazem pensar em seres suprasensíveis que seriam sua causa última... seres à imagem desmesuradamente aumentada daquilo que nos afeta..." São os signos hermenêuticos ou interpretativos. Ou, como quer Deleuze, os ídolos metafísicos.

Esses quatro tipos de signos escalares, correspondentes a quatro tipos de afecções (efeitos físico-sensíveis, efeitos abstrativos, efeitos morais, efeitos imaginários), combinam-se necessariamente com os chamados signos vetoriais, com os três tipos de signos vetoriais de afecto. Os dois tipos principais e polares: as potências aumentativas (conforme o vetor seja de aumento, crescimento, alegria) e as servidões diminutivas (conforme o vetor seja de diminuição, decréscimo, tristeza). E ainda um terceiro tipo: os signos ambíguos ou flutuantes, quando uma afecção a um só tempo aumenta $e$ diminui nossa potência, nos afeta ao mesmo tempo de alegria e de tristeza. $\mathrm{Na}$ 
verdade, todos esses seis ou sete tipos diferentes de signos não cessam de se (re)combinar.

As características comuns a todos os signos são a associabilidade (entram em diferentes cadeias de associação), a variabilidade (variam para cada povo, para cada artista $e$, mesmo, para cada um) e a equivocidade (as interpretações são fundamentalmente equívocas para cada associação variável). É a mistura, o que prevalece nessa fonte inesgotável de ilusões que é a potência imaginativa da alma: não apenas as associações variáveis de signos escalares entre si, mas, necessariamente, as combinações de signos escalares com signos vetoriais ("os afectos supõem sempre afecções de onde derivam, embora não se reduzam a elas"); e não se deve excluir nem mesmo que os signos vetoriais de afecto entrem, entre si, em associações variáveis...

Os signos vetoriais em geral, isto é, os afectos, entram em associações variáveis tanto quanto as afecções: o que é crescimento para uma parte do corpo pode ser diminuição para outra parte, o que é servidão de um é potência de outro, e uma ascensão pode ser seguida de uma queda $e$ inversamente. (Deleuze, 1997, p.158)

Estas seriam as linhas gerais da plástica e dinâmica "semiótica" espinosana, essa fascinante visão do signo e da vida imaginativa e afetiva, mas que também poderia ser dita um pequeno tratado do conhecimento inadequado. De fato, com o que foi exposto até aqui, continuamos sem uma resposta para a questão, agora formulada por Deleuze: "como chegamos nós a ter, a formar idéias adequadas, uma vez que nossa condição natural nos determina a não ter senão idéias inadequadas?" (Deleuze, 2002, p.85)

Esse conhecimento pelos signos ou imaginação, que Espinosa também nomeia de "conhecimento por experiência vaga", "conhecimento por ouvir dizer" ou, simplesmente, "opinião", corresponde ao conhecimento de primeiro gênero (cf. escólio II da proposição 40 do livro 2). A bem dizer, esse primeiro gênero mal chega a ser um conhecimento, posto que é apenas "experiência vaga": são "idéias confusas de misturas entre corpos, imperativos brutos para evitar tal mistura e buscar tal outra e interpretações mais ou menos delirantes dessas situações. É uma linguagem material afetiva..." Se o conhecimento pelos signos e pela imaginação só pode ser um conhecimento confuso e inadequado, é de se esperar que qualquer caminho para o conhecimento adequado só possa se fazer contra os signos e a imaginação. Na Ética, que é filosofia do conhecimento adequado, espera-se que eles sejam os mais duramente criticados. Contudo, não é exatamente assim que Espinosa, o racionalista, coloca a questão...

Não há dúvida de que na vida imaginativa, que é a vida das paixões, não apenas produzimos idéias inadequadas (causalidades imaginárias), como também somos causa inadequada do que sentimos, fazemos e desejamos, porque somos causa apenas parcial de tudo isso. E isso, para Espinosa, por uma razão muito simples e bastante evidente: porque a força dos corpos exteriores sobre nós é imensamente maior do que a força de nossos corpos individuais, a exterioridade sobrepuja a interioridade causal corporal e psíquica (cf. Chauí, 1995, p.65). É exatamente o que diz a proposição 3 do livro 4 ("Da servidão humana ou da força dos afetos"). Ademais, este também é o princípio da idéia espinosana de servidão humana: ser servo de causas externas, estar "sob o poder" de outro.

Mas a vida imaginativa, como já vimos, pode também ser uma virtude, 
quando a potência imaginativa se liberta. E como essa potência imaginativa pode se libertar? Ou, em que condições passamos a ser causa livre dessa potência? O que é preciso para entrar "na posse dessa potência" e nos tornarmos "capazes de formar um conceito"? Quando deixamos de ser passivopassionais e assumimos a iniciativa do conhecimento?

... é preciso efetivamente que ao menos certos signos nos sirvam de trampolim e que certos afectos nos proporcionem o impulso necessário (Livro V). No encontro ao acaso entre corpos podemos selecionar a idéia de certos corpos que convêm com o nosso e que nos dão alegria, isto é, aumentam nossa potência. E só quando nossa potência aumentou suficientemente, a um ponto sem dúvida variável para cada um, entramos na posse dessa potência e nos tornamos capazes de formar um conceito, começando pelo menos universal (conveniência de nosso corpo com algum outro), mesmo se na seqüência devemos atingir conceitos cada vez mais amplos segundo a ordem de composição das relações. Há portanto uma seleção dos afectos passionais, e das idéias de que eles dependem, que deve liberar alegrias, signos vetoriais de aumento de potência, e repelir as tristezas, signos de diminuição: tal seleção dos afectos é a própria condição para sair do primeiro gênero de conhecimento $e$ atingir o conceito adquirindo uma potência suficiente. Os signos de aumento continuam sendo paixões, $e$ as idéias que eles supõem permanecem inadequadas: nem por isso deixam de ser os precursores das noções, os sombrios precursores... Nos signos, portanto, há alguma coisa que ao mesmo tempo prepara e duplica os conceitos... E a Ética não pode privar-se de uma forma de expressão passional e por signos, única capaz de operar a indispensável seleção sem a qual permaneceríamos condenados ao primeiro gênero. (Deleuze, 1997, p.162-3)

Esse é, efetivamente, um dos traços mais fortes e peculiares da filosofia de Espinosa: pensamos e agimos adequadamente não contra os afectos, mas graças a eles. A vida ética, a virtude e o conhecimento adequado (que coincidem, na medida que todos implicam, similarmente, numa interiorização da causalidade e na instauração de uma nova relação com a exterioridade), não começam por uma idéia adequada, mas por uma paixão. Para Espinosa, uma paixão não pode ser vencida por uma idéia adequada, mas só por uma paixão mais forte (prop. 1 do livro 4). Há, assim, um processo libertador que se gesta no interior das paixões: à medida que as paixões tristes vão sendo afastadas $e$ as alegres vão sendo aproximadas, a força do conatus aumenta; $e$ a alegria $e o$ desejo que decorrem desse aumento preparam-nos para a atividade e diminuem a passividade.

Trata-se, outra vez, do problema de se fazer um $\mathrm{CsO}$, isto é, de se saber estabilizar as intensidades num platô e se reconhecer a partir do plano de imanência do desejo (o plano de consistência da alegria), o que significa imediatamente um aumento das potências, um aumento da força do conatus. $O$ essencial de se compreender, nesse ponto, é como esse aumento das potências, enquanto uma forte disposição para assumir a iniciativa da ação e do conhecimento, implica fundamentalmente numa interiorização da causalidade: tanto na ação, quanto no conhecimento, uma diminuição das causas externas imaginárias e um reconhecimento da força da "causação" interna. É a própria idéia espinosana da liberdade humana: "reconhecer-se como causa eficiente interna dos apetites e das imagens, dos desejos e das idéias, afastando a 
miragem ilusória das causas finais externas" (Chauí, 1995, p.72).

Na vida imaginativa, somos causa inadequada de nossos atos e a potência é pura força de perceber e experimentar, só se realizando como paixão. A vida ética começa quando - por selecionarmos as coisas e as idéias que nos dão alegria e aumentam a nossa potência -, "entramos na posse dessa potência" $e$ passamos a produzir noções comuns ou conceitos, assim como nos tornamos causa adequada de nossos atos, que só podem se realizar como virtude. Passemos, então, a examinar o que são as noções comuns ou o que Espinosa chama de conhecimento de segundo gênero. Antes, porém, um comentário precioso de Deleuze sobre esse problema da "seleção dos afectos", ao qual deveremos voltar, mas que, desde já, pretendemos evitar que dele se tenha uma visão enganosamente simplista, como se se tratasse de um problema menor ou de um não-problema, uma passagem já resolvida na fabricação de conceitos. Pode parecer demasiado simples: "para entrarmos em posse dessa potência, basta selecionarmos as coisas que nos dão alegria..." Como se já não residisse aí, toda uma ampla gama de dificuldades decisivas neste processo. Como se não se tratasse, também neste caso, de atravessar o Grande Risco:

Essa seleção é muito dura, muito difícil. É que as alegrias e as tristezas, os aumentos e as diminuições, os esclarecimentos e os assombreamentos costumam ser ambíguos, parciais, cambiantes, misturados uns aos outros. E sobretudo muitos são os que só podem assentar seu Poder na tristeza e na aflição, na diminuição de potência dos outros, no assombreamento do mundo: fingem que a tristeza é uma promessa de alegria e já uma alegria por si mesma. Instauram o culto da tristeza, da servidão ou da impotência, da morte. Não param de emitir e impor signos de tristeza, que apresentam como ideais e alegrias às almas que eles mesmos tornaram enfermas. É o caso do par infernal, o Déspota e o Sacerdote, terríveis 'juízes' da vida. A seleção dos signos ou dos afectos como primeira condição para o nascimento do conceito não implica, pois, só o esforço pessoal que cada um deve fazer sobre si mesmo (Razão), mas uma luta passional, um combate afetivo inexpiável em que se corre risco de vida, onde os signos afrontam os signos e os afectos se entrechocam com os afectos, para que um pouco de alegria seja salva, fazendo-nos sair da sombra e mudar de gênero. Os gritos da linguagem dos signos marcam essa luta das paixões, das alegrias e das tristezas, dos aumentos e diminuições de potência. (Deleuze, 1997, p.163)

\section{O conceito e a fabrica intima}

Quando encontramos um corpo que convém com o nosso, experimentamos um afecto de alegria-paixão; esta alegria-paixão, como aumento da potência de agir e compreender, nos induz a conhecer, em primeiro lugar, o que temos em comum com aquele corpo que nos convém e qual a essência dessa relação de conveniência; em outras palavras, nos induz a formar uma noção comum, a qual só pode ser um conhecimento adequado ${ }^{14}$. A tristeza, que nasceria de um encontro com um corpo que não convém com o nosso, logicamente, jamais nos induziria a fazer uma noção comum. Quando chegamos a fazer uma noção comum, atingimos o que Espinosa chama de conhecimento de segundo gênero ou "razão" (ratio). Como se deduz, para Espinosa o homem não nasce "razoável", mas pode vir a sê-lo por meio da alegria. Daí, justamente, sua dupla definição da razão:

\footnotetext{
${ }^{14}$ Livro 2: Proposição

38: "Aquilo que é

comum a todas as coisas e que está igualmente na parte $e$ no todo, só pode ser concebido adequadamente." Corolário: "Daqui se segue que há certas idéias ou noções comuns a todos os homens. Pois todos os corpos concordam em certas coisas, as quais devem ser percebidas por todos adequadamente, ou seja, clara e distintamente." Proposição 39:

"Daquilo que é comum e próprio do corpo humano e de certos corpos exteriores pelos quais o corpo pode ser afetado, e que se dá igualmente na parte e no todo de qualquer um deles, haverá também na alma uma idéia adequada." Corolário: "Daqui se segue que a alma é tanto mais apta a perceber

adequadamente muitas coisas, quanto mais coisas em comum tem seu corpo com outros corpos."
} 
1. um esforço para selecionar e organizar os bons encontros, a saber, os encontros dos modos que se compõem conosco e inspira-nos paixões alegres (sentimentos que convêm com a razão); $2^{\circ}$ ) a percepção $e$ compreensão das noções comuns, isto é, das relações que entram nessa composição, de onde se deduzem outras relações (raciocínio) e a partir das quais se experimentam novos sentimentos, desta vez ativos (sentimentos que nascem da razão). (Deleuze, 2002, p.100)

A noção comum não é uma noção comum a todos os espíritos. Pode até vir a sê-lo, secundariamente. Mas, primeiramente, é uma noção comum aos corpos: é “a representação de uma composição entre dois ou vários corpos, e de uma unidade dessa composição... ela exprime as relações de conveniência ou de composição dos corpos existentes..." Nada, entretanto, nessa idéia de noção comum, remete às ficções e abstrações do método geométrico (que ainda marcavam a visão de Espinosa no Tratado da correção do intelecto, 1658); seu sentido é mais biológico do que matemático; são generalidades, mas só referidas aos modos existentes...

... não são de modo algum fictícias ou abstratas: elas representam a composição das relações reais entre modos ou indivíduos existentes. Enquanto a geometria não capta senão relações in abstracto, as noções comuns permitem que captemos tais como são, isto é, tais como estão necessariamente encarnadas nos seres vivos, com os termos variáveis e concretos entre os quais se estabelecem. (Deleuze, 2002, p.101)

Interessa-nos, especialmente, compreender como se formam as noções comuns, o que Espinosa nos explica no início do famigerado livro 5. Vejamos a proposição 10: "Durante o tempo em que não somos atormentados pelos afetos que são contrários à nossa natureza, temos o poder de ordenar e encadear as afecções do corpo segundo uma ordem relativa ao entendimento." Comentando esta proposição, Deleuze afirma que há duas idéias implícitas, que se ocultam no imenso hiato aberto entre a oração subordinada e a principal: a idéia de conveniência entre dois corpos e a idéia de noção comum:

Entre a subordinada e a principal se evidencia uma falha imensa, um intervalo, pois os afectos contrários à nossa natureza nos impedem antes de tudo de formar noções comuns, já que eles dependem de corpos que desconvêm com o nosso; ao contrário, cada vez que um corpo convém com o nosso, e aumenta nossa potência (alegria), uma noção comum aos dois corpos pode ser formada, de onde decorrerão uma ordem e um encadeamento ativos das afecções. (Deleuze, 1997, p.169)

Essa seria, então, a condição básica, decisiva, determinante, para que uma noção comum possa se formar: a relação de conveniência entre os corpos. É a partir daí que uma noção comum pode se formar e sempre, em primeiro lugar, como uma compreensão interna e adequada das próprias razões de conveniência. Mas a formação das noções comuns também sempre se continua no sentido de noções cada vez mais gerais (não no sentido de mais abstratas, nem necessariamente mais universais, mas no sentido de mais compostas). É Deleuze, uma vez mais, que nos oferece uma sistematização inteligente dessa ordem de formação:

As primeiras noções comuns são pois as menos gerais, as que representam 
algo de comum entre meu corpo e outro que me afeta de alegria $e$ paixão; $2^{\circ}$ ) dessas noções comuns decorrem por sua vez afetos de alegria, que já não são paixões, porém alegrias ativas que vêm, por um lado, superar as primeiras paixões, e por outro substituílas; $3^{\circ}$ ) essas primeiras noções comuns e os afetos ativos que delas dependem dão-nos força para formar noções comuns mais gerais, exprimindo o que há de comum, mesmo entre nosso corpo e corpos que não lhe convêm, que lhe são contrários ou o afetam de tristeza; $4^{\circ}$ ) e dessas novas noções comuns decorrem novos afetos de alegria ativa que vêm ultrapassar as tristezas e substituir as paixões nascidas da tristeza. (Deleuze, 2002, p.100)

Espinosa, partindo da potência imanente do ser de se conhecer ${ }^{15}$, postula que nos modos de existência que são os corpos, o que há para se conhecer, em primeiro lugar, são as composições (relações de conveniência) que aumentam sua potência (de se conhecer). É através de afectos (paixões) de alegria e crescimento, que passamos dos signos às noções comuns e é ainda através de afectos aumentativos (embora não mais paixões, mas afectos ativos de alegria, afectos "que nascem da razão"16), que passamos para noções cada vez mais gerais, cada vez mais compostas. E assim procede a alma, de composição em composição, sempre seguindo os arranjos que aumentem sua potência, até alcançar um limiar em que até mesmo as composições "diminutivas" poderão ser consideradas.

Essa ordem de formação das noções comuns nos revela que o pensamento, para Espinosa, se define por um particular construtivismo: construção de noções comuns, enquanto composição de "uma ordem e um encadeamento ativos das afecções", uma ordem e um encadeamento livremente definidos pelo entendimento, que compreende "de dentro" as relações de conveniência entre os corpos, suas relações internas constitutivas, e não mais, como a imaginação, apenas as relações externas de um corpo sobre outro, enquanto seqüências associativas e generalizadoras de imagens instantâneas gravadas em nossa carne... E é por ser uma construção ou uma composição livremente definida pelo entendimento (nossa potência interna para pensar), que o pensamento também pode ser definido como criação.

É importante, neste ponto, deixar um pouco mais clara a idéia de liberdade em Espinosa, idéia que não se encontra mais em oposição à idéia de necessidade, tal como se apresenta em toda a tradição filosófica clássica desde Aristóteles, que colocou a natureza do lado da necessidade eterna e a ação humana do lado da contingência. O pensamento judaico-cristão desloca para a própria ação de Deus essa concepção aristotélica de uma ação contingente, atribuindo-Lhe livre vontade. Espinosa se esforçou em demonstrar que essa imagem de Deus (à imagem e semelhança do homem) é tão ilusória quanto a própria imagem de um homem cuja liberdade se definiria pela vontade livre. A liberdade humana, para Espinosa, não é o livre-arbítrio, ela não se prova pela contingência de nossas ações. Na Ética, o filósofo demonstra que Deus age necessariamente, isto é, segundo as leis necessárias de sua potência, e é esta sua liberdade e sua perfeição - o poder de autodeterminar-se à ação -, e não a idéia imaginária de que Ele aja segundo uma vontade onipotente e um intelecto onisciente, o que faz da Criação um resultado caprichoso do "juízo de Deus", que tanto poderia ser como não ser. Igualmente para o homem: a liberdade humana também é o
${ }^{15}$ Livro 5: Proposição 36:

"O amor intelectual da alma por Deus éo mesmo amor com que Deus se ama a si mesmo, não enquanto Deusé infinito, mas na medida em que pode ser explicado através da essência da alma humana, considerada da perspectivada

eternidade, o que quer dizer que o amor

intelectual da alma por Deus é uma parte do amor infinito com que Deus se ama a si mesmo."

Complexa, como quase todas as proposições do livro 5, esta proposição subverte completamente o discurso religioso. Espinosa fala em "amor intelectual" e afirma que "Deus se ama a si mesmo", ou seja, Deus se conhece. Contudo, isso não significa uma autoconsciência da substância, o que Espinosa demonstrou ser impossível, visto que uma "autoconsciência" já seria um modo. Portanto, se Deus se conhece, essa

"autoconsciência" não se dá no intellectus absolute infinitus, que é absolutamente impessoal e está para além de toda consciência, mas no único lugar do sistema modal do pensamento em que se dá a "reflexão" da realidade: o pensamento humano. É nos homens que Deus se ama e se conhece.

${ }^{16}$ Cabe destacar que, "em igualdade de condições", é máximo o afecto que experimentamos em relação a alguma coisa que imaginamos livremente; muito maior do que em relação a coisas que a alma entende como necessárias (cf. proposições 5 e 6 do livro 5). Ou ainda, cf. proposição 7: "Os afectos que brotam da razão ou que são suscitados por ela são mais potentes que os que se referem a coisas singulares tomadas como ausentes." 
${ }_{17}$ Livro 2: Proposição 15: "A idéia que constitui o ser formal da alma humana não é simples, mas composta de muitíssimas idéias."

Demonstração: "A idéia que constitui o ser formal da alma é a idéia do corpo, o qual se compõe de muitíssimos indivíduos mui compostos. Pois bem: há

necessariamente uma idéia em Deus de cada indivíduo composto de um corpo. Logo, a idéia do corpo humano está composta destas numerosíssimas idéias de suas partes componentes. Q.E.D." poder de autodeterminar-se à ação ou, como diz Espinosa, o poder de ser a "causa adequada" de seus atos. Somos livres quando agimos segundo a necessidade de nossa natureza. A liberdade, para Espinosa, não se opõe à necessidade; ela é o conhecimento da necessidade. A liberdade é a força interior do corpo e da alma para produzir e acolher a multiplicidade simultânea de movimentos corporais, afectos e idéias. Ela não é simplesmente escolha, mas a autodeterminação necessária e a alegria de vida.

É por isso que a Ética pode ser dita, ao mesmo tempo, uma ontologia do necessário e um tratado da liberdade humana. Uma ontologia do necessário contra uma "ontologia ou metafísica do possível"; uma liberdade que não é simplesmente "contingência ou livre-arbítrio". A "metafísica do possível" é uma ontologia imaginária. Arriscaríamos dizer que, talvez, resulte, em última instância, dos efeitos imaginários de outrem: o nosso corpo finito percebe outrem como infinitamente diverso e imprevisível; outrem não é apenas um mundo possível, mas uma infinidade de mundos possíveis, entre os quais não podemos, num primeiro momento, estabelecer quaisquer relações, o que pode nos fazer crer que são contingentes $e$ atribuir a outrem (e, conseqüentemente, nós) um livre-arbítrio. E não se trata apenas de um efeito imaginário, mas de um efeito moral, um signo imperativo: Escolha! Para Espinosa, entretanto, não se trata de dizer que não há escolhas (aliás, há várias a se fazer, guiadas pela razão), mas de que não é a escolha que dá substância à liberdade humana que, tanto quanto tudo que é, nada tem de contingente. A liberdade não é simplesmente poder escolher, mas só começa com as escolhas certas: ela só é atingida quando, graças à razão (ao conhecimento), fazemos as escolhas necessárias, aquelas que aumentam consistentemente nossa potência e alegria de vida.

Fica mais claro, assim, o que pode significar essa idéia de uma composição criada, de uma construção livremente definida pelo entendimento. Mas, notemos, além disso, como esse caráter construído das noções comuns ressalta determinadas características dos modos de existência do atributo pensamento que prolongam características já examinadas dos modos de existência do atributo extensão - como que confirmando a consubstancialidade dos atributos. Vimos, assim, como o corpo, para Espinosa, é um indivíduo composto de "muitíssimos indivíduos (de diversa natureza), cada um dos quais é mui composto" e entra em composição com "muitíssimos outros corpos". O mesmo se dá no caso da alma17: as noções comuns (conhecimento adequado do corpo) também são fundamentalmente relações de composição cada vez mais compostas e o conhecimento adequado dessas relações. Como são constitutivamente relações de conveniência, esse conhecimento adequado corresponde, de fato, a um conhecimento das relações de afecto positivo e, conseqüentemente, ao conhecimento de nossos próprios afectos (o que é o primeiro conhecimento adequado que podemos ter dos corpos que nos causam alegria), portanto, um conhecimento afetivo e interior, um conhecimento vivo e encarnado.

Essa liga afetiva conecta ao infinito os componentes de uma noção comum ou de um corpo, e estes entre si, formando indivíduos cada vez mais compostos, de tal modo que, tanto para a extensão como para o pensamento, tanto num plano ontológico quanto gnosiológico, as soluções efetivamente se encaminham no sentido da chamada "multiplicidade de fusão": seja de indivíduos extensos (corpos e energias físicas) constituídos por relações de movimento e repouso, rapidez e lentidão; seja de indivíduos 
intensos (idéias e signos de todo tipo) constituídos por encadeamentos e nexos ${ }^{18}$.

A Imaginação só capta a sombra de um corpo sobre outro; a luz é apenas refletida ou absorvida pelos corpos que fazem sombra. Já no caso da Razão, conhecimento de segundo gênero, a luz "torna os corpos transparentes ao revelar-lhe a 'estrutura' íntima (fabrica)." Não é mais só a projeção da sombra do objeto no nosso corpo, mas a luz revelando a fabrica intima como verdadeiro objeto, quando fabricamos uma noção comum, um conceito desse objeto. E o que constitui essa fabrica intima? Trata-se de...

... uma relação composta, de movimento e repouso, de velocidade e lentidão, que se estabelece entre as partes infinitamente pequenas de um corpo transparente. Como as partes vão sempre por infinidades maiores ou menores, em cada corpo há uma infinidade de relações que se compõem e se decompõem, de maneira que o corpo por sua vez penetra num corpo mais vasto, sob uma nova relação composta, ou, ao contrário, põe em evidência os corpos menores sob suas relações componentes... A estrutura é ritmo, isto é, encadeamento de figuras que compõem e decompõem suas relações... A estrutura tem vários corpos em comum e remete a um conceito de objeto, isto é, a uma noção comum. A estrutura ou o objeto é formado por dois corpos pelo menos, sendo cada um destes formado por dois ou mais corpos ao infinito, que se unem no outro sentido em corpos cada vez mais vastos e compostos, até o único objeto da Natureza inteira, estrutura infinitamente transformável e deformável, ritmo universal, Facies totius Naturae, modo infinito. (Deleuze, 1997, p.160)

Ora, por esse caminho rumo ao mais e mais composto, chega-se a mais geral das noções comuns, a que exprimiria o que há de mais comum entre todos os modos existentes: que eles estão em Deus e são produzidos por Deus. Contudo, essa noção ainda não chega a ser uma idéia adequada de Deus porque, mesmo o modo mais infinitamente infinito, todavia é modo e não substância. É nesse sentido que Espinosa diz que a própria idéia de Deus não pode ser em si mesma uma noção comum, porque uma noção comum só diz respeito aos modos existentes e, portanto, a algo que possa ser imaginado, o que, certamente, não se aplica à idéia de Deus. Para se chegar ao que Espinosa chama de idéia adequada ou intelecto de Deus - que, para além dos modos existentes, deve alcançar a essência de Deus -, devemos ascender ao conhecimento de terceiro gênero, que o filósofo também chama de "ciência intuitiva" ou "certeza intelectual". Há, assim, um segundo limiar do conhecimento adequado, que nos transpõe para além da Razão. A Razão já é conhecimento adequado, mas...

... quando as noções comuns nos conduzem necessariamente à idéia de Deus, fazem-nos atingir um ponto em que tudo oscila e o terceiro gênero nos vai descobrir a correlação entre a essência de Deus e as essências singulares dos seres reais, com um novo sentido da idéia de Deus e de novos sentimentos constitutivos desse terceiro gênero. Não há pois ruptura do segundo ao terceiro gênero, mas passagem de uma vertente a outra da idéia de Deus: passamos para além da Razão como faculdade das noções comuns ou sistema das verdades eternas referido à existência, entramos no entendimento intuitivo como
${ }^{17}$ Livro 2: Proposição 15: "A idéia que constitui o ser formal da alma humana não é simples, mas composta de muitíssimas idéias." Demonstração: "A idéia que constitui o ser formal da alma é a idéia do corpo, o qual se compõe de

muitíssimos indivíduos mui compostos. Pois bem: há

necessariamente uma idéia em Deus de cada indivíduo composto de um corpo. Logo, a idéia do corpo humano está composta destas numerosíssimas idéias de suas partes componentes. Q.E.D."

${ }^{18} \mathrm{Um}$ primeiro componente desta idéia, por referência ao atributo extensão, se encontra na definição de corpo como um "indivíduo composto" que está no livro 2:

"Quando certos corpos, de igual ou distinta magnitude, são compelidos pelos demais corpos de tal modo que se aplicam uns contra outros, ou então - se é que se movem com igual ou distinto grau de velocidade - de modo tal que comuniquem uns aos outros seus movimentos, segundo uma certa relação diremos que estes corpos estão unidos entre si e que todos juntos compõem um só corpo, ou seja, um indivíduo que se distingue dos demais por meio da dita união de corpos" (Spinoza, 1998; p.133).

Mas, é no escólio do lema 7 , que

encontramos o sentido plenamente ontológico da "multiplicidade de fusão": "... um indivíduo composto pode ser afetado de muitas maneiras, conservando, não obstante, sua natureza. E até agora, concebemos um indivíduo que só se compõe de corpos, que só se distinguem entre si pelo movimento e o 
repouso, a rapidez $e$ a lentidão, isto é, que se compõe de corpos mais simples. Se agora, concebemos outro, composto de vários indivíduos de distintas naturezas, acharemos que pode ser afetado de muitas outras maneiras, conservando, não obstante, sua natureza. Com efeito, suposto que cada uma de suas partes está composta de vários corpos, cada parte poderá, sem câmbio algum de sua natureza, mover-se mais lenta ou mais rapidamente, $e$, por conseguinte, comunicar seus movimentos às outras mais depressa ou mais devagar. Se

concebemos, ademais, um terceiro gênero de indivíduos, composto de indivíduos de segundo gênero, acharemos que pode ser afetado de muitas outras maneiras, sem câmbio algum de sua forma. Ese

continuamos assim até o infinito, concebemos facilmente que toda a natureza é um único indivíduo, cujas partes - isto é, todos os corpos - variam de infinitas maneiras, sem câmbio algum do indivíduo total..." (pp.135-6) sistema das verdades de essência (às vezes chamado consciência, visto que só aí as idéias se desdobram ou refletem em nós, tais como são em Deus, e nos fazem experimentar que somos eternos). (Deleuze, 2002, p.101-2)

Há ruptura entre o primeiro e segundo gênero de conhecimento: embora sejam certas paixões (idéias inadequadas) que nos induzam a formar noções comuns (idéias adequadas) e embora também estas últimas dependam de certas características da imaginação, há real ruptura entre os dois gêneros, separando o inadequado do adequado, substituindo os afectos passivos por afectos ativos. Já entre o segundo e o terceiro gênero, há apenas diferença de natureza, "passagem de uma vertente a outra da idéia de Deus": ambos são conhecimentos adequados, só que as noções comuns se aplicam apenas aos modos existentes, enquanto o terceiro gênero é o conhecimento das verdades de essência.

É no livro 5 que Espinosa trata do conhecimento de terceiro gênero. Embora a Ética seja basicamente conhecimento de segundo gênero, é para o terceiro gênero que convergem todos seus esforços, é a ele que se quer chegar, a que se deve chegar, aquele a que, o mais difícil e o mais raro, é se chegar. Não são mais signos ou afectos, nem conceitos ou noções comuns, mas "Essências ou Singularidades":

É o terceiro estado da luz. Não mais signos de sombra nem a luz como cor, mas a luz em si mesma e por si mesma. As noções comuns (conceitos) são reveladas pela luz que atravessa os corpos e os torna transparentes; elas remetem, pois, a figuras ou estruturas geométricas (fabrica), tanto mais vivas quanto são transformáveis e deformáveis num espaço projetivo... Mas as essências são de uma natureza inteiramente diferente: puras figuras de luz produzidas pelo Luminoso substancial (e não mais figuras geométricas reveladas pela luz)... são em si mesmas 'contemplações', isto é, contemplam tanto quanto são contempladas, numa unidade de Deus, do sujeito ou do objeto... As noções comuns remetem a relações de movimento e de repouso que constituem velocidades relativas; as essências, ao contrário, são velocidades absolutas que não compõem o espaço por projeção, mas o preenchem de uma só vez, num único golpe... São estas, contudo, as duas características das essências: velocidade absoluta e não mais relativa, figuras de luz e não mais figuras geométricas reveladas pela luz. A velocidade relativa é a das afecções e dos afectos: velocidade da ação de um corpo sobre outro no espaço, velocidade da passagem de um estado a outro na duração. O que as noções apreendem são relações entre velocidades relativas. Mas a velocidade absoluta é a maneira pela qual uma essência sobrevoa na eternidade seus afectos e suas afecções (velocidade de potência). (Deleuze, 1997, p.166-7)

Podemos, enfim, retornar a Robinson, após este largo recurso à filosofia de Espinosa. Acreditamos que os elementos de sua filosofia que foram abordados permitem uma compreensão adequada de diversos aspectos da aventura de Robinson, em especial, de como conseguiu alcançar a Grande Saúde. A bem dizer, é a filosofia espinosana que, em grande parte, nos inspira e oferece vários dos componentes do conceito de Grande Saúde que estamos propondo, partilhando uma enorme zona de indiscernibilidade 
conceitual com sua noção de "virtude suprema", isto é, com sua Ética (parafraseando Deleuze \& Guattari: o grande livro da Grande Saúde não seria a Ética?). Mas para se supor uma região em que conhecimento de terceiro gênero, vida ética e saúde sejam indiscerníveis, é preciso incluir a idéia, bastante espinosana e já afirmada no início deste texto, de que a filosofia é uma forma de vida, ou ainda, de que "os gêneros de conhecimento são modos de existência, porque o conhecer prolonga-se nos tipos de consciência e de afetos que lhe correspondem, de sorte que todo o poder de ser afetado seja necessariamente preenchido" (Deleuze, 2002, p.64).

A ética do conceito

Robinson sobreviveu à neurose e à psicose e conquistou um modo de viver na imanência. Com o desmoronamento da estrutura Outrem, Robinson teve que conquistar um modo de habitar nas malhas do caos. Essa foi a sua conquista da Grande Saúde e ela guarda semelhanças com as aventuras de conquista da arte, da ciência ou da filosofia: um modo de criar e criar-se a partir do caos. Robinson logrou habitar o caos, como o fazem os verdadeiros artistas, cientistas e filósofos, mas Robinson o logrou da maneira mais integral possível e, por isso, falamos aqui de uma Grande Saúde. Mesmo Espinosa, manifestamente, só o atingiu no nível da "potência da alma"19. Robinson o atingiu não apenas no plano de uma potência ou outra de seu ser, mas em sua integralidade, numa experiência de integração total de um homem (e depois outro homem) com a natureza de uma ilha deserta.

No entanto, ainda não está inteiramente claro como e porque Robinson o conseguiu. Já sabemos que a experiência de desabamento da estrutura Outrem o coloca face a face com o plano de imanência do desejo, com a imagem verticalizada do mundo, o que potencialmente lança seu ser no oceano Caos; já sabemos também que não sucumbiu no oceano Caos, porque soube conservar para si um "pedaço de nova terra". Mas isso ainda não é suficiente para explicar porque, como Robinson conseguiu. A circunstância concreta de isolamento numa ilha selvagem talvez explique porque sua aventura acabe sendo a de um envolvimento tão integral de seu ser (e não apenas da alma ou de uma de suas potências), que é o que, afinal, determina que o resultado de sua conquista seja a Grande Saúde (e não o resultado que poderia advir de conquistas realizadas num ou outro plano). Mas ela não é capaz, por si só, de explicar seu sucesso.

O nosso entendimento é que Robinson alcançou a Grande Saúde, isto é, logrou viver a imanência do desejo, por dois motivos, um deles definitivo: o log-book e Sexta-Feira.

Em última instância ou no limite, Robinson só conseguiu porque, mais tarde, surgiu um outro homem na ilha: Sexta-Feira. Sim, pois podemos conceber que, como o Corpo sem Órgãos, o Mundo sem Outrem também é um limite: não se chega totalmente a um $\mathrm{CsO}$, como não se sobrevive até o fim a um MsO. No limite, Robinson só conseguiu porque, enfim, chegou outrem. Entretanto, pode-se dizer também que só conseguiu porque esse outrem que chegou não abalou sua trajetória rumo à Grande Saúde. Pelo contrário, deu-lhe um impulso ainda mais decisivo. Houvera sido outro

\author{
19 No prefácio do livro \\ 5 , em que trata da \\ maneira de alcançar o \\ conhecimento de \\ terceiro gênero, ou seja, \\ a liberdade, ou ainda, a \\ felicidade, Espinosa \\ esclarece: "De que \\ maneira e por que \\ método deva \\ aperfeiçoar-se o \\ entendimento $e$ \\ mediante que arte deva \\ se cuidar do corpo a \\ fim de que possa \\ cumprir retamente suas \\ funções, são questões \\ que não pertencem a \\ este lugar; o último \\ concerne à Medicina, o \\ primeiro, à Lógica. Aqui, \\ tratarei somente da \\ potência da alma, ou \\ seja, da razão..." \\ (Spinoza, 1998, p.383).
}


"outrem" (um compatriota inglês, protestante, por exemplo) e é bem possível que a "velha" estrutura Outrem se restaurasse. Mas foi Sexta-Feira, este outro ser solar, quem veio terminar de parir esta Grande Saúde em Robinson, quem veio ajudar para que se completasse a metamorfose de Robinson em Sexta-Feira.

Num momento em que a ilha já era coabitada por Sexta-Feira e, portanto, num momento em que seu isolamento já não era absoluto, mas que era, assim mesmo, um isolamento que se extremava num passo que ultrapassava duas décadas, Robinson escreve em seu log-book uma espécie de sumário dos vários momentos pelo qual passou até a chegada de Sexta-Feira, distinguindo com clareza o papel que este desempenha no avanço de sua metamorfose:

\begin{abstract}
Mas é certo que, flutuando numa solidão intolerável que só me dava a escolha entre a loucura e o suicídio, procurei instintivamente o ponto de apoio que o corpo social já não me fornecia. Ao mesmo tempo, as estruturas construídas e mantidas em mim pelo comércio dos meus semelhantes caíam em ruínas e desapareciam. Assim, por tentativas sucessivas, era levado a procurar a minha salvação na comunhão com os elementos, tornando-me eu próprio elementar. A terra de Speranza trouxe-me uma primeira solução durável e viável, ainda que imperfeita $e$ perigosa. Depois surgiu inesperadamente Sexta-Feira e, subjugando-se na aparência ao meu reinado telúrico, destruiu-o com todas as suas forças. Havia, no entanto, um caminho de salvação, pois se Sexta-Feira tinha uma aversão absoluta à Terra, ele era, por nascença, tão elementar quanto eu o era por acaso. Sob sua influência, sob os golpes sucessivos que me desferiu, avancei na estrada de uma longa e lenta metamorfose.

(Tournier, 1985, p.197)
\end{abstract}

Até que Sexta-Feira aparecesse, ainda a tempo para a "salvação final" de Robinson, o que sustentou, mesmo que de maneira precária, vacilante, oscilante, sua trajetória rumo à Grande Saúde, o que lhe permitiu fazer um CsO sem desaparecer num buraco negro da ilha, foi, segundo o próprio Robinson, a "terra de Speranza". Em sua "comunhão com os elementos", que fez com que ele mesmo se tornasse elementar, foi Speranza, como já dissemos, que representou seu "pedaço de nova terra". Contudo, seguindo as lições de Espinosa, argumentamos que, se no mundo extenso foi Speranza que representou o seu "pedaço de nova terra", no mundo intenso, sua "reterritorialização relativa" se deu pela via do conhecimento. Argumentamos que Robinson conseguiu sobreviver graças, fundamentalmente, ao conhecimento de suas afecções e de seus afectos, graças ao fato de jamais ter abandonado a prática de refletir sobre o que se passava consigo. Em outras palavras, à ética dos signos, Robinson soube agregar uma ética dos conceitos, e por isso - e somente por isso - pôde não apenas fazer para si um $\mathrm{CsO}$, mas através dele, ou melhor, nele, alcançar a Grande Saúde, o que só se fez definitivamente possível com a chegada de Sexta-Feira.

Essa nossa interpretação sobre o que sustenta o ânimo de Robinson até a chegada de Sexta-Feira, reverbera um aspecto do pensamento de Espinosa que costuma ser tratado como uma "implantação gnóstica" em sua filosofia: a "salvação" só pode ser definitivamente alcançada pelo conhecimento. Portanto, para os homens, o mais sólido pilar da "salvação" seria a potência 
de sua alma de formar idéias claras e distintas de seus afectos (que deixam, assim, de ser paixões), sem que esse conhecimento, no entanto, implique qualquer tipo de supressão dos afectos, mas sim, sua substituição progressiva por afectos ativos ${ }^{20}$. Nesse sentido, é que podemos dizer que o caminho para a Grande Saúde passa por se fazer um CsO, mas apenas na medida em este se apresenta como o primeiro passo para se alcançar o conhecimento adequado. O caminho para a Grande Saúde passa pelo $\mathrm{CsO}$, o que significa que passa pela descoberta do bom caminho para o desejo (quando este aprende qual é seu verdadeiro objeto), o que é o mesmo que alcançar a alegria imanente do desejo e experimentar um aumento das potências que seja capaz de nos conduzir ao conhecimento adequado das afecções e dos afectos. Em última instância, o caminho para a Grande Saúde depende do conhecimento adequado das afecções e dos afectos, simetricamente ao que está afirmado na proposição 28 do livro 5: " $O$ esforço ou o desejo de conhecer as coisas segundo o terceiro gênero de conhecimento não pode surgir do primeiro, mas sim do segundo".

E Robinson não o teria conseguido, se tivesse mantido a face apenas voltada para o plano de imanência do desejo, o que certamente teria significado um mergulho irreversível no caos. Mas ele soube também voltar sua face para esta outra face, para essa autêntica fácies, na medida em que uma autêntica "superfície de expressão": as páginas de seu diário. Foi ele, este pequeno e frágil artefato, que permitiu que Robinson preservasse a possibilidade de deflagrar a reflexão, mesmo quando esta já havia deixado de lhe ser "natural". Desde muito cedo, no seu processo de transformação, ele começa a anotar suas reflexões no log-book e manterá este gesto (que contrai toda nossa potência "reflexiva" em sua própria instrumentalidade), mesmo numa fase já avançada de sua "desumanização". É claro que o logbook pode ser visto apenas como um meio, o que por si só não garantiria nenhuma filosofia. Mas, um meio nunca é apenas um meio e, não raramente, ele é o meio, razão pela qual nunca deveríamos subestimar seu papel. É claro também que, depois que um meio viabilizou algo (que talvez nem fosse possível sem ele), aí sim, que esse meio realmente não interessa mais (e tanto mais não interessa, quanto melhor cumpriu seu papel), quando tão somente passa a interessar o que ele viabilizou. E o que viabilizou, para Robinson, escrever sobre o sentido de suas experiências?

Viabilizou a Filosofia. A experiência radical do MsO combinada ao esforço de selecionar os melhores afectos - seleção efetuada não apenas em ato, mas também no ato de escrever sobre esses afectos, seleção que já é ato da Razão - conduziram Robinson à possibilidade de formar noções comuns e, no caso, noções comuns necessariamente novas, de tal forma a darem conta das novas ameaças de caos que se impunham pela ausência dos efeitos estruturantes de outrem. Entre as primeiras das novas noções compostas por Robinson, a própria noção de Outrem.

Já sabemos que é a partir da estrutura Outrem - por uma espécie de "tomada de poder" dos modos de se estabelecer mundos possíveis e se regular as leis de transição entre os mundos - que se conformam os "mitos $e$ instituições que permitem ao desejo tomar corpo". Em sociedade, Robinson, "o mais positivo, o menos especulativo dos homens", jamais se inclinaria a filosofar. Mas, na medida em que sua catástrofe de proporções biográficas o conduziu até os limbos do Caos, criar conceitos ou fazer filosofia, tornaram-se questões de vida ou morte...

E Robinson soube criá-los: em parte, porque experimentou um grande

\author{
${ }^{20}$ Livro 5: Proposição 3 : \\ "Um afecto que é uma \\ paixão deixa de ser \\ uma paixão, tão logo \\ dele formamos uma \\ idéia clara e distinta." \\ E, no escólio da \\ proposição 4, afirma \\ que: primeiro, "há que \\ se notar que o apetite \\ pelo qual se diz que o \\ homem age $e$ o apetite \\ pelo qual se diz que o \\ homem padece são um \\ e o mesmo"; segundo, \\ "todos os apetites ou \\ desejos são paixões na \\ medida em que brotam \\ de idéias inadequadas \\ $e$, são atribuíveis à \\ virtude, quando \\ suscitados ou \\ engendrados por idéias \\ adequadas"; portanto, \\ "todos os desejos que \\ nos determinam a fazer \\ algo podem brotar \\ tanto de idéias \\ adequadas quanto \\ inadequadas; e não há, \\ sob nosso poder, um \\ melhor remédio para \\ os afectos: aquele que \\ consiste no seu \\ verdadeiro \\ conhecimento, posto \\ que a alma não tem \\ outra potência que não \\ seja a de pensar $e$ \\ formar idéias \\ adequadas."
}


aumento das potências quando a libido passou a fluir para os elementos livres, para a natureza "liberada" da ilha; em parte, porque ao registrar essa experiência, passo a passo, em seu log-book, acabou por realizar um processo de autoconhecimento dos afectos, dos novos afectos que experimentava $e$, principalmente, das novas relações de conveniência que descobria - de resto, relações de conveniência com "corpos" até então desconhecidos, porque ocultados, encobertos, envelopados por Outrem.

De um lado, ergue-se, fosforescente, com luz própria, o "duplo glorioso do mundo"; de outro, Robinson, com sua luz própria, ilumina as novas relações de composição que vivencia. Em suma, estão reunidas as condições supremas da criação filosófica. O que significa que, certamente, está presente o desejo de se conhecer as coisas em suas essências singulares ou segundo o terceiro gênero de conhecimento, ainda que, em nenhum momento do romance, a busca de um tal conhecimento, por si mesmo, se explicite como uma meta para Robinson. É que, no seu caso, essa busca se efetua enquanto a busca mais inclusiva e decisiva da Grande Saúde. É desse modo que podemos entender porque esse terceiro gênero de conhecimento não irrompe triunfal em Robinson, como prêmio pela conquista intelectual longamente trabalhada, mas vai se insinuando, pouco a pouco, de maneira quase involuntária, nas formas de seu entendimento, como uma sabedoria que vai se revelando insidiosamente, como novos afectos ativos de alegria (na verdade, "o maior contentamento possível da alma"), como "momentos de inocência", que se manifestam, primeiramente, modificando sua percepção e seus afectos em relação à terra de Speranza e, depois, em relação ao homem Sexta-Feira, tal como podemos apreender numa certa altura de seus registros no log-book, quando escreve sobre...

$$
\begin{aligned}
& \text {... esses breves deslumbramentos que eu por vezes tinha e a que } \\
& \text { chamava, não sem intuição divinatória, 'os meus momentos de } \\
& \text { inocência'. Parecia-me então entrever, durante um curto instante, uma } \\
& \text { outra ilha escondida sob o estaleiro de construção e a exploração } \\
& \text { agrícola com que eu cobrira Speranza. Essa outra Speranza, eis-me } \\
& \text { transportado agora nela, eis-me para sempre instalado num 'momento } \\
& \text { de inocência'. Speranza já não é uma terra inculta que é preciso fazer } \\
& \text { frutificar. Sexta-Feira já não é um selvagem que é meu dever morigerar. } \\
& \text { um e outra requerem toda minha atenção, uma atenção contemplativa, } \\
& \text { uma vigilância maravilhada, pois parece-me - não, tenho certeza - que } \\
& \text { os descubro pela primeira vez, a cada instante, e que nada ofusca a sua } \\
& \text { mágica novidade. (Tournier, 1985, p.192-3) }
\end{aligned}
$$

Insistimos, entretanto, que sempre nos parece insuficiente definir a experiência de Robinson como filosofia, pois, como já dissemos, ela implica uma tal integralidade, isto é, um envolvimento tão integral do ser de Robinson, que não podemos restringi-la às "potências da alma" ou a outra potência qualquer, mas só podemos concebê-la como comprometendo a totalidade de seu ser composto e componente de uma totalidade maior. Em suma, o que Robinson realmente experimenta são as condições supremas para se perfazer a Grande Saúde. Portanto, mais que filosofia ou, talvez, finalmente, a Filosofia: quando conhecimento das verdades de essência, vida ética e saúde coincidem. E quando coincidem, já não se trata mais apenas de uma "saúde adequada", mas, de uma certa forma, "a passagem de uma vertente a outra da idéia” de saúde, quando a própria saúde é apreendida 
como verdade de essência, o que significa o conhecimento da própria essência da saúde, ou seja, para além dos planos modais, o que poderia ser propriamente entendido como uma Saúde da substância ou Saúde de Deus sem que nenhum tipo de idéia "antropomorfizante" esteja contida nesta última expressão, assim como não há nenhum tipo de antropomorfização quando Espinosa fala em Intelecto de Deus. Basta lembrar a já discutida proposição em que afirma que Deus se ama e se conhece na alma humana (cf. nota 15). Da mesma forma que a "consciência" do Intelecto de Deus não se dá no intelectus absolute infinitus, tampouco a "consciência" da Saúde de Deus pode se dar como substância (que, ademais, só pode liberar uma idéia puramente positiva de saúde - uma Grande Saúde! -, pois que nada saberia limitá-la, em sua imanência absoluta). Então, similarmente, se há uma Saúde de Deus ou uma Saúde da substância, ela só pode ser atingida como "consciência" no homem, na medida em que se trata do único "lugar" no sistema modal da substância dotado de uma potência interna para pensar e, portanto, capaz de realizar os conhecimentos de segundo e terceiro gênero.

O que aconteceu com Robinson, por acidente (mas, ao cabo, também por sua força própria), é o que pode haver de mais raro e mais difícil, assim como o mais raro e o mais difícil é que alguém se disponha, livremente, a trilhar tão árduo caminho. Porém...

... se a via que conduz a essa conquista parece mui árdua, é possível, entretanto, achá-la. E árduo certamente deve ser o que tão raramente se encontra. Com efeito: se a salvação estivesse ao alcance da mão $e$ pudesse ser conseguida sem grande trabalho, como poderia suceder que quase todos a desdenhem? Mas, todo o excelso é tão difícil quanto raro. (Spinoza, 1998, p.428)

\section{A Grande Saúde é o Tao}

O Tao é o Caminho, o bom caminho, o fortalecimento do conatus, a saúde do $\mathrm{CsO}$.

Para Lao-tsé, o velho filósofo - talvez, um contemporâneo de Confúcio (séculos VI-V a.C.), autor do célebre Tao-tê-king (O Caminho e sua virtude) , o Tao (Caminho) é a origem de todas as coisas e de todos os seres do universo, o princípio cósmico imanente de toda existência humana e de toda atividade da natureza. O tê (virtude) é sua eficácia, sua virtus espontânea $e$, nesse sentido, bem diferente da virtude confuciana, inteiramente submetida aos juízos e artifícios da civilização. É esse modo de vincular ontologia e ética, o que interessantemente aproxima o taoísmo e a filosofia espinosana. Para ambos, a sabedoria é o conhecimento do Tao e a virtude é o viver em conformidade com o Tao.

O Caminho lhes dá vida

A Virtude as cria

A espécie lhes dá forma

O meio as acaba

Também é unanimemente que todas as coisas Adoram o Caminho e veneram a Virtude Não que adorar o Caminho

Venerar a Virtude

Sejam deveres ditados: é inclinação natural

Assim portanto é o Caminho que lhes dá a vida

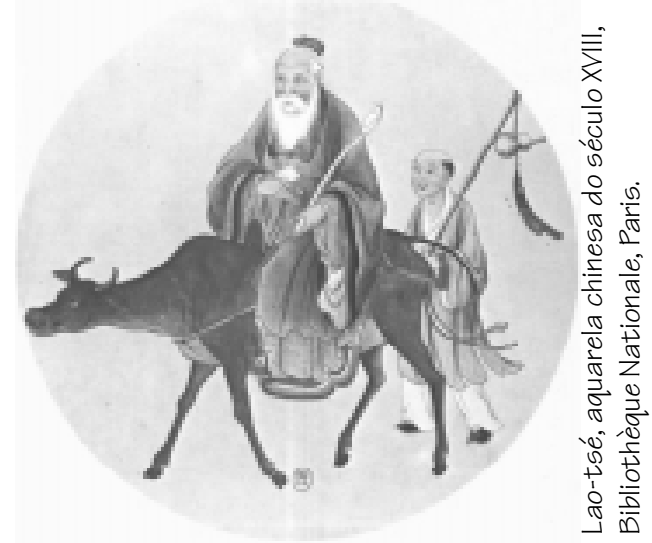


A GRANDE SAÚDE: UMA INTRODUÇÃO À ...

É a Virtude que as cria

Que as sustenta e as faz crescer

Que as abriga e as conforta

Que as alimenta $e$ as protege.

(Lao-tzeu, 1979, p.121)

A Grande Saúde é o Tao-tê: o Caminho e sua virtude.

A Grande Saúde é a Ética.

A felicidade é a virtude: essa virtus espontânea, que é a eficácia própria da substância, de seu esforço de perseverar em ser.

Conforme a última proposição do livro 5: "A felicidade não é um prêmio que se outorga à virtude, mas é a própria virtude, e não gozamos dela porque reprimimos nossas concupiscências, mas, ao contrário, podemos reprimir nossas concupiscências porque dela gozamos."

Para Espinosa, o bom e o mau não são valores em si, nem correspondem a qualidades que existiriam nas próprias coisas. Bom é, simplesmente, tudo quanto aumente a força do conatus; mau, tudo quanto a diminua.

Conforme já vimos, não desejamos algo porque é bom, mas é bom porque o desejamos. É por isso que Espinosa pode afirmar na belíssima proposição 21 do livro 4: "Ninguém pode desejar ser feliz, agir bem e bem viver que não deseje ao mesmo tempo ser, agir e viver, isto é, existir em ato". E na proposição seguinte diz textualmente: "Não se pode conceber nenhuma virtude anterior ao esforço de se conservar". Em outras palavras, para Espinosa, a virtude é o conatus. Em sua Ética, virtude não tem o sentido moral de adequação a um modelo, mas o sentido originalmente dado em seu étimo latino de uma "força interna", de "robustez, vigor" (virtus deriva de vis, "força, poder, influência").

Acreditamos que, pelo que foi exposto até aqui, já está inteiramente claro que é em torno da idéia de fortalecimento do conatus (Tao) que se constitui a zona de indiscernibilidade conceitual entre conhecimento da verdade, vida ética e saúde. Para Espinosa, há não apenas uma alegria, mas também uma liberdade e uma verdade imanentes do desejo.

Grande Saúde = Verdade, Liberdade, Felicidade.

A Ética, para Espinosa, enquanto vivência da felicidade, da liberdade e da verdade, decorre do conhecimento da "causa absoluta do real", que é a "substância infinitamente infinita" e o "bem verdadeiro". A Grande Saúde (ou a Ética) decorre do desejo de conhecer e compartilhar com os outros, o "bem imperecível capaz de se comunicar igualmente a todos".

Já vimos, e de diversas formas, como o fortalecimento do conatus está estreitamente relacionado ao encontro do desejo com esse "bem verdadeiro", o que significa sempre um aumento de nossa potência interna de formar "idéias adequadas", o que é, afinal, o mesmo que a "adequação" de nossos afectos ativos, em termos de sentimentos e de ações, incluindo tanto o modo como afetamos (e nos afetamos), quanto o modo pelo qual somos afetados pelo mundo. Pois, como também já dissemos, citando Deleuze, "o conhecer prolonga-se nos tipos de consciência e de afetos que the correspondem, de sorte que todo o poder de ser afetado seja necessariamente preenchido".

Se tudo depende de desejarmos o "bem verdadeiro", então, a grande questão, ou a passagem em que realmente tudo se decide, deve ser mesmo a da "seleção dos afectos", isto é, das idéias e dos corpos que convêm com o 
nosso. Não há dúvida de que, em boa medida, a Grande Saúde (ou a Ética) depende da maneira como, ao interiorizarmos a causalidade, passamos a nos relacionar com as coisas e as forças externas. Depende da maneira como, ao entrarmos na posse da potência que permite a seleção dos afectos de alegria, nos conduzimos ao encontro com o verdadeiro objeto do desejo, "o bem imperecível capaz de se comunicar igualmente a todos". É nesse sentido que podemos entender a postulação espinosana de que o desejar (nossa alegria imanente e nossa potência de agir e pensar) depende inteiramente da qualidade do desejado, de "que toda nossa infelicidade e toda a nossa felicidade dependem da qualidade do ser ao qual nos unimos por amor" (Espinosa, no Tratado da correção do intelecto, citado por Chauí, 1995, p.38).

Vemos, então, que há duas questões claramente destacadas no pensamento de Espinosa: a identidade da virtude com o fortalecimento do desejo e a dependência da força do desejo da qualidade do desejado. $\mathrm{O}$ filósofo nos oferece uma síntese eloqüente, aproximando essas duas questões, no escólio da proposição 18 do livro 4:

... Como a razão não exige nada que seja contrário à natureza, exige, por conseguinte, que cada qual se ame a si mesmo, busque sua utilidade própria - o que realmente lhe seja útil -, apeteça tudo aquilo que conduza realmente o homem a uma perfeição maior, e, em termos absolutos, que cada um se esforce, do modo que estiver a seu alcance, para conservar seu ser... Supondo-se, ademais, que a virtude não é outra coisa senão atuar segundo as leis da própria natureza, e que ninguém se esforça em conservar seu ser senão em virtude das leis de sua própria natureza, daí se segue: primeiro, que o fundamento da virtude é o esforço mesmo de conservar o ser próprio, e a felicidade consiste no fato de que o homem saiba conservar seu ser. Segue-se também, segundo: que a virtude deve ser apetecida por si mesma, e que não devemos apetecê-la por obra de outra causa mais excelente ou útil para nós do que a própria virtude. Segue-se, por último, terceiro: que os que se suicidam são de ânimo impotente e estão completamente derrotados por causas exteriores que repugnam a sua natureza. Ademais, segue-se, que não podemos prescindir de tudo que nos é externo para conservar nosso ser, e que não podemos viver sem ter algum comércio com as coisas que estão fora de nós... Assim, pois, há muitas coisas fora de nós que nos são úteis e que, por isso, hão de ser apetecidas. E entre estas, as mais excelentes são as que concordam por completo com nossa natureza. Com efeito: se, por exemplo, dois indivíduos que têm uma natureza inteiramente igual se unem entre si, compõem um indivíduo duplamente mais potente do que cada um deles em separado. E assim, nada é mais útil ao homem que o homem; quero dizer que nada podem desejar, os homens, que seja melhor para a conservação de seu ser que o concordar todos em todas as coisas, de sorte que as almas de todos formem como que uma única alma e seus corpos como que um só corpo, esforçando-se todos, ao mesmo tempo, o quanto puderem, em conservar seu ser, e buscando todos a uma comum utilidade ${ }^{21}$; de onde se segue que os homens que se governam pela razão, isto é, os homens que buscam a utilidade guiados pela razão, não apetecem para si nada que não desejem para os demais homens e, por isso, são justos, dignos de confiança e honestos. (Spinoza, 1998, p.306-8)
${ }^{21}$ Nesse ponto, encontramos a melhor intersecção das idéias aqui trabalhadas com o pensamento político de Espinosa. Fica fácil entender porque, para Espinosa, o bem

comum não é a finalidade da política, mas o eventual efeito de uma política adequada aos interesses $e$ aos costumes dos cidadãos que a instituíram:

"diferentemente de Hobbes, Espinosa recusa tanto a idéia de contrato social quanto de alienação do direito natural no direito civil. De fato, quando os homens, em estado de Natureza, descobrem as vantagens de unir forças para a vida em comum, não fazem pactos nem contratos, mas formam a multidão ou a massa como algo novo: $O$ sujeito político. $A$ massa, constituindo um sujeito único, cria um indivíduo coletivo cujo conatus é mais forte e superior ao de cada um dos indivíduos isolados. Esse conatus coletivo é o soberano ou o Estado civil. Dessa maneira, ninguém transfere a um outro o direito e o poder para governá-lo mas cada um e todos conservam, aumentando, o direito natural, agora transformado em direito civil e Estado" (Chaui, 1995; p. 76).

"Assim como a liberdade individual exprime a força do corpo e da alma enquanto causas adequadas de suas afecções, afetos e idéias, assim também a liberdade política só se realiza quando o direito civil (as leis) e o Estado (as instituições de governo) fortalecem o conatus coletivo, em lugar de enfraquecê-lo e subjugá-lo no medo, na ilusão supersticiosa e nas promessas de recompensas numa vida celeste futura para os ofendidose

humilhados nesta vida" (Chauí, 1995, p.78-9). 
No dia em que a tripulação da escuna de bandeira inglesa Whitebird desembarcou em Speranza, a permanência de Robinson na ilha contabilizava exatamente vinte e oito anos, dois meses e dezenove dias. O comandante William Hunter, num primeiro momento intrigado com o surpreendente personagem e "seu serviçal mestiço", convida Robinson para uma visita à embarcação, onde lhe oferece um almoço e pede para que seu imediato the apresente os últimos avanços da tecnologia naval. Tão logo saltou para a ponte do Whitebird, Robinson foi invadido por "uma certa tristeza, tanto mais quanto sentia crescer nele um movimento de oposição a este universo para o qual o arrastavam, parecia-lhe, contra a vontade"...

Robinson almoçou com o comandante e o imediato... Não precisou se esforçar para alimentar a conversa. Os seus hospedeiros pareciam ter admitido, de uma vez para sempre, que ele tinha tudo a aprender com eles e nada a revelar de si e Sexta-Feira, e Robinson acomodava-se perfeitamente a esta convenção que lhe permitia observar e meditar à vontade. A bem dizer, era verdade, num certo sentido, que tinha tudo a aprender, tudo a assimilar, a digerir, mas o que ouvia era tão pesado e indigesto como as terrinas e as carnes ensopadas que desfilavam no prato, e seria de temer que um reflexo de recusa o fizesse vomitar em bloco o mundo e os costumes que, aos poucos, ia descobrindo.

No entanto, o que mais lhe repugnava não era tanto a brutalidade, o ódio $e$ a ganância que estes homens civilizados e altamente honoráveis demonstravam com inocente tranqüilidade. Ficava sempre a possibilidade de imaginar - e sem dúvida seria fácil encontrar - outros homens que, no lugar destes, fossem amáveis, indulgentes e generosos. Para Robinson, o mal era bem mais profundo. No seu íntimo, reconhecia-o na irremediável relatividade dos fins que os via a todos perseguir febrilmente. Pois o que todos tinham como objetivo era tal aquisição, tal riqueza, tal satisfação, mas porque esta aquisição, esta riqueza, esta satisfação? Decerto ninguém saberia dizê-lo. E Robinson imaginava, sem cessar, o diálogo que certamente acabaria por o confrontar com um destes homens, o comandante por exemplo. 'Por que vives tu?', perguntar-lhe-ia. Hunter, evidentemente, não saberia o que responder, e o seu único recurso seria devolver a pergunta ao Solitário. Então Robinson mostrar-lhe-ia com a mão esquerda a terra de Speranza, enquanto levantaria a direita para o Sol. Após um momento de espanto, o comandante rebentaria a rir, riso de loucura perante a sabedoria, pois como poderia ele conceber que o Astro Maior é alguma coisa mais que uma chama gigantesca, que nele houvesse espírito e poder para irradiar de eternidade os seres que soubessem abrir-se a ele? (Tournier, 1985, p.211-2)

Robinson-solar descobriu o "bem imperecível capaz de se comunicar igualmente a todos". Em sua Grande Saúde, observa aqueles homens, com os quais já se assemelhou, e distingue meridianamente este "traço deplorável do espírito ocidental" que é sempre referir seu desejo a fins exteriores e relativos: "bens perecíveis", cujo valor se funda justamente em se extraírem ao compartilhamento, o que, para Espinosa, jamais poderá trazer a felicidade, pois a inveja e a cobiça que a posse exclusiva de tal bem atrairá, não permitirá que seu possuidor tenha paz e tranqüilidade. Por isso, os homens que buscam a utilidade guiados pela razão, só desejam para si o que pode ser compartilhado 
pelos demais homens.

O Astro Maior e a Terra são certamente "bens imperecíveis capazes de se comunicar igualmente a todos" $e$, se Robinson chegou a descobri-lo, foi graças ao conhecimento, este outro "bem imperecível..." Quando os homens, como Robinson, passam a se guiar pelo conhecimento, já não desejam nada mais para si que não possa ser igualmente desejado e compartilhado por outros homens.

E nada desejam mais do que o conhecimento.

Com o intuito de oferecer uma síntese esquemática dos encadeamentos $e$ nexos aqui estabelecidos, selecionamos as seguintes proposições do Livro 4:

\footnotetext{
Proposição 24: "Em nós, atuar absolutamente segundo a virtude não é outra coisa senão agir, viver ou conservar seu ser (estas três coisas significam a mesma coisa), guiados pela razão; pondo como fundamento a busca da própria utilidade."

Proposição 26: "Todo esforço que realizamos segundo a razão não é outra coisa senão conhecimento, e a alma, na medida em que usa a razão, não julga útil senão o que a leva ao conhecimento."

Proposição 33: "Os homens podem diferir em natureza, na medida em que sofrem afectos que são paixões; e, nessa mesma medida, um mesmo homem é volúvel e inconstante." Proposição 34: "Na medida em que os homens sofrem afectos que são paixões, podem ser contrários entre si."

Proposição 35: "Os homens só concordam sempre necessariamente em natureza, na medida em que vivem guiados pela razão."

Proposição 36: "O supremo bem dos que seguem a virtude é comum a todos e todos podem gozar dele igualmente."

Demonstração: Agir segundo a virtude é agir guiado pela razão, e todo esforço realizado por nós, segundo a razão, é conhecimento, e, desta sorte, o supremo bem dos que seguem a virtude consiste em conhecer a Deus, isto é, um bem que é comum a todos os homens e que pode ser possuído igualmente por todos os homens, enquanto são da mesma natureza. Q.E.D.

Escólio: ... o fato de que o supremo bem do homem seja comum a todos, não nasce de um acidente, senão da natureza mesma da razão, pois isso se deduz, indubitavelmente, da própria essência humana, enquanto definida pela razão, e o homem não poderia ser, nem se conceber, se não tivesse a potência de gozar deste supremo bem. Assim, pois, é próprio da essência da alma humana ter um conhecimento adequado da eterna e infinita essência de Deus."
}

\section{A medicina espinosana}

De um ponto de vista espinosano, a mais alta missão da medicina deve ser a de criar, para os corpos e as almas, as melhores condições para que se amplie a potência humana de perfazer a verdade, a liberdade e a felicidade, alcançando, assim, a Grande Saúde (ou a Ética). E, se ela pode cumprir tal missão, é porque os meios que mobiliza tomam parte em nossas possibilidades e qualidades de ser-existir-agir, aumentando ou diminuindo, de forma significativa, nossas chances de chegar ao conhecimento do necessário.

A medicina espinosana é a medicina do $\mathrm{CsO}$ e para o médico espinosano, em sua teoria e sua prática, os problemas de saúde se colocam em dois grandes planos articulados: num primeiro, o maior problema de saúde da humanidade é a inapetência ou a diminuição das potências e da alegria de viver, cuja expressão mais eloqüente e atual é, sem dúvida, a verdadeira epidemia de quadros depressivos que flagela as sociedades modernas - as quais reconhecemos como sociedades permanente $e$ intensivamente irradiadas pelos mais diversos signos de diminuição de potência, que nos são, entretanto, muitos deles, oferecidos 
${ }^{22}$ Por

biotecnomedicina,

designamos a forma

hegemônica da

medicina

contemporânea,

herdeira legítima da

medicina positiva $e$

experimental do século

XIX e primeira metade

do século $\mathrm{XX}$, e que

vem se constituindo,

mais recentemente, no

cenário particularmente

"espetacularizado" da

tecnociência de ponta.

Trata-se, de fato, de um

prolongamento

extrovertido da

iatromecânica, que

estabelece, com esse

prolongamento, uma

particular

"continuidade" de

elementos conectados -

que vão desde

componentes bio-

moleculares, até

compostos tecno-

molares -, e que

constitui o único $e$

mesmo objeto desta

medicina: uma única $e$

mesma fabrica intima

relacionando

componentes

descontínuos,

distribuídos num

mesmo espaço de

representação. Uma

multiplicidade

conectada de

componentes

mecânicos, homogêneos

e quantitativos, em

tudo distinta do

continuum que se

estabelece na duração,

quando não são mais

ligações mecânicas, mas

forças intensivas que

conectam (ou não) seus

componentes,

formando uma

multiplicidade

conectada de "estados"

qualitativamente

heterogêneos. como promessas de salvação, mas que, na realidade, são só novas servidões, alegrias sem consistência, incapazes de nos conduzir a uma

autodeterminação positiva de nossas potências (nesse plano, o que tem realmente importância, para a medicina espinosana, é o conhecimento dos signos vetoriais); num segundo plano, colocam-se os problemas (cujo enfrentamento pressupõe uma saúde mínima no primeiro plano) relacionados à qualidade do desejado, o que, em nosso entender, é praticamente um problema "ambiental" (e, nesse plano, o que importa é o conhecimento dos signos escalares). Cremos que tenha ficado claro, na forma como expusemos o pensamento de Espinosa, que estes dois planos estão inteiramente relacionados, são mesmo inseparáveis e sua separação é meramente esquemática, prestando-se apenas para ressaltar duas dimensões do mesmo processo. E qual é esse processo, que faz uma unidade destas duas dimensões (fortalecimento do desejo e qualidade do desejado)? $\mathrm{O}$ processo de "seleção dos afectos". A grande questão para a medicina espinosana, afinal, é: quais os afectos que efetivamente aumentam nossa potência, quais os afectos de alegria consistente?

Como já vimos, a questão é das mais complexas, pois os signos são terrivelmente confusos e misturados. $\mathrm{E}$, ao longo da história humana, jamais faltaram aqueles (déspotas e sacerdotes!) prontos para nos impor signos de tristeza, como se se tratassem da própria alegria, para nos propor um caminho de salvação fundado na tristeza e na diminuição de potência, um caminho de libertação que só pode ser uma nova forma de servidão. Para Espinosa (assim como, mais tarde, para Nietzsche), foram os déspotas e os sacerdotes do judaísmo e do cristianismo que desempenharam, emblematicamente, este papel na história do Ocidente.

Postulamos que, contemporaneamente, é a chamada biomedicina ou biotecnomedicina ${ }^{22}$ que desempenha, em boa parte, este papel outrora desempenhado pelas religiões: impor signos de tristeza como se fossem o caminho para a felicidade ou a própria felicidade, novas "servidões" como se fossem "libertações". Por exemplo, todas as preocupações que passam a reger uma vida orientada pela noção de risco (pela possibilidade de que determinados corpos não convenham com o nosso), tal como é proposta pelas principais práticas atuais de medicina preventiva, promovem, do ponto de vista espinosano, servidões diminutivas (como são os afectos de medo), que podem, entretanto, se transformar em potências apenas fracamente aumentativas (como são os afectos de esperança), na dependência de uma salvação que só poderá ser obtida por suas próprias promessas biotecnológicas: toda diminuição de potência promovida pelo conhecimento dos riscos que nos ameaçam e nos rondam constantemente (e cujo caráter "totalitário" fica tanto mais evidente quando nos damos conta de que várias destas condições de risco dizem respeito a aspectos de nossa vida "normal"), só pode ser recuperada através dos objetos de salvação da própria medicina. Inventa o pecado e inventa a salvação do pecado. Ou, mais propriamente, inventa a salvação, que inventa o pecado.

Sob este ponto de vista, indiscutivelmente, há uma concorrência histórica da tecnociência moderna com as religiões monoteístas tradicionais, que vem se resolvendo numa relativa complementaridade (que, talvez, apenas prepare o caminho para uma total confluência), ambas instaurando, em termos deleuzeanos, "o culto da tristeza, da servidão ou da impotência, da morte. Não param de emitir e impor signos de tristeza, que apresentam como ideais e alegrias às almas que eles mesmos tornaram enfermas”. $E$ 
exatamente por que é a medicina em sua versão biotecnológica que desempenha este papel, hoje em dia, que se torna importante advertir que, quando falamos numa medicina espinosana, não queremos, de modo algum, nos referir a mais um tipo de "juiz da vida", a um outro modo de se exercer esse papel de "juiz da vida". Não se trata mais de "impor signos", sejam eles quais forem, uma vez que, apenas por serem signos impostos, já são "diminutivos". No mínimo, não são capazes de conduzir à verdadeira "libertação" do estado de padecimento, já que apenas representa a submissão do paciente a uma outra causalidade externa: a de suas práticas de salvação. Se há um possível médico espinosano, que não se pretende mais um "juiz da vida", qual seria, então, seu papel junto àquele que padece?

Sendo a principal questão, sempre, a da "seleção dos afectos" (e, em última instância, a do aumento das potências), é nesse processo que o médico espinosano deverá tomar parte. Mas o seu papel não é o daquele que já descobriu, de uma vez por todas, quais são os verdadeiros afectos "aumentativos" e, por isso, pode impô-los, "salvificamente" e sem maiores objeções morais, a seus pacientes. O seu papel deve ser participar deste processo como quem participa de um conflito, de uma disputa, sempre em aberto, não decidida. Deve ter claro também que, mesmo quando participa deste processo junto a um paciente individual, se trata sempre, mais que tudo, de um problema supraindividual. Não é para cada um, individualmente, que este problema da "seleção dos afectos" não está resolvido (nem tampouco para a humanidade que, para este tipo de problema, se constitui numa abstração vazia), mas para os grandes conjuntos humanos, com seus planos coletivos de felicidade. Sua solução não pode resultar apenas de uma ação reflexiva operada sobre si mesmo, pois as formas culturais e societárias podem ser sempre consideradas como uma solução já dada a respeito de quais são os autênticos afectos de alegria e potência. E é nesse sentido que se pode dizer que a medicina espinosana é uma espécie de "Saúde Pública" ou, pelo menos, de "medicina coletiva" ou "do coletivo" 23 . Já dissemos acima que ela, de uma certa forma, tem diante de si um problema "ambiental" e, deste ponto de vista, ela só pode ser uma "medicina ambiental". Mesmo quando é "medicina do corpo", ela continua a ser uma "medicina ambiental", já que o corpo pode ser visto, conectadamente, como uma "região" deste "ambiente". A medicina espinosana, quando é "medicina do corpo" continua a ser uma "medicina ambiental", só que da "região" mais sensível deste "ambiente", a "região" mais decisiva para a "saúde ambiental". E por que? Simplesmente porque é nessa "região" do CsO que Deus se conhece e se ama, porque só aí pode se dar a "consciência" na/da substância infinitamente infinita, a "consciência" da Saúde substancial.

Um "estado de corpo" é sempre um "estado de mundo", e nossa alma (onde Deus se ama e se conhece) sempre sabe, mais que tudo, da vida de seu próprio objeto, da vida de seu próprio corpo. Em outras palavras, mesmo que ela saiba dos "estados de corpo" enquanto conhecimento dos "estados de mundo", ela sempre sabe melhor (porque apenas sabe por meio) dessa "região" do mundo que é seu corpo, já que é nele que se projetam os "signos escalares", já que é ele o "instrumento de medida" - o métron do mundo, embora não no sentido de "medida do mundo" e, sim, de lugar onde o mundo se mede.

Temos, em suma, que as modificações nos corpos exteriores, as modificações no mundo, afetam fortemente e determinam os "estados de corpo", mas estes sempre nos informam muito mais do próprio corpo e, por isso, as modificações que se dão no corpo são ainda mais fortemente capazes de alterar nossas

\author{
${ }^{23}$ Aproximamo-nos, \\ uma vez mais, das \\ concepções \\ nietzscheanas, que \\ definem \\ duplamente o \\ filósofo: como um \\ médico da alma \\ (curando-a do \\ niilismo pela \\ afirmação de uma \\ auto-superação e \\ uma auto-perfeição \\ contínua e criativa) \\ e como um médico \\ da cultura \\ (desafiando os \\ princípios \\ prevalentes e \\ forçando a \\ sociedade e seus \\ indivíduos a \\ reconhecere \\ incorporar \\ anomalias a sua \\ própria \\ Weltanschauung), \\ conforme breve \\ sistematização \\ oferecida por \\ Tauber (2001).
}


percepções e sensações (bem como nossas possibilidades de ação), ou seja, o modo como somos afetados pelo mundo (e o afetamos). Retomando a proposição 16 do livro 2 (nota 21), poderíamos agregar um terceiro corolário: se modificamos a constituição de nosso próprio corpo, também, certamente, modificamos as idéias de nossas afecções (as características dos "signos escalares"), já que elas nos informam muito mais da natureza de nosso próprio corpo de que dos corpos exteriores. Acrescentaríamos ainda que uma modificação corporal compromete, imediatamente, a formação dos chamados signos físico-sensíveis e abstrativos $e$, um pouco mais mediadamente, a formação dos signos imperativos e interpretativos (mais mediada, por exemplo, pelo "corpo social", que estabelece os modos de produção e distribuição dos meios de modificação corporal). Em outras palavras, os símbolos morais e os ídolos metafísicos, os chamados efeitos morais e imaginários, estão mais ordinariamente implicados nos planos coletivos de felicidade de um dado conjunto humano.

Em síntese, a grande questão para a medicina espinosana é realmente a da "seleção dos afectos", que se apresenta, esquematicamente, em dois planos: o da seleção dos "signos escalares" (perspectiva que a faz uma "medicina ambiental") e o da seleção dos "signos vetoriais aumentativos" (perspectiva que detém, afinal, o objetivo último desta medicina, qual seja: promover o aumento das potências que conduza ao conhecimento da verdade, da liberdade e da felicidade).

E se o médico espinosano não é mais uma reedição da velha figura do sacerdote, qual mesmo seu papel junto ao paciente? Talvez, a melhor maneira de cumprir seu papel, seja praticando uma espécie de "maiêutica da alegria", seja ajudando a parir a Grande Saúde em seus pacientes, que deixam, assim, de ser pacientes, entrando na posse de suas potências... Ele deve ser um facilitador no nosso processo de busca do que realmente precisamos para ser felizes, e um crítico amigo das soluções ilusórias a que vamos nos apegando pelo caminho. Apesar de sua experiência e sabedoria, ou melhor, por causa delas, o médico espinosano não é aquele que traz a resposta, é aquele que não nos deixa esquecer da pergunta: quais, realmente, os corpos $e$ as idéias que nos convêm, quais os afectos de autêntica alegria? Como estes questionamentos dizem respeito, de fato, a intensas lutas passionais e coletivas, a missão do médico espinosano deve ser, em primeiro lugar, garantir as condições para que estes violentos conflitos sejam os menos sangrentos e dolorosos possíveis, permitindo sempre que "alguma alegria seja salva". Sua arma principal: o conhecimento (dos afectos, das paixões). Mas, ainda que o conhecimento possa ser o melhor "remédio", a medicina espinosana não perde de vista que o verdadeiro pilar de nossa "salvação" é realmente a alegria (já que apenas ela nos dá potência suficiente para conhecer).

\section{Referências}

CHAUÍ, M. S. Espinosa, uma filosofia da liberdade. São Paulo: Moderna, 1995.

COUTO, M. Terra sonâmbula. Lisboa: Caminho, 1992.

DELEUZE, G. Spinoza e as três "Éticas". In: DELEUZE, G. Crítica e clínica. São Paulo: Ed. 34, 1997. p.156-70.

DELEUZE, G. Michel Tournier e o mundo sem outrem In: DELEUZE, G. Lógica do sentido. São Paulo: Perspectiva, 1998. p.311-30. 
TEIXEIRA, R. R.

DELEUZE, G. Espinosa: filosofia prática. São Paulo: Escuta, 2002.

DELEUZE, G., GUATTARI, F. O que é a Filosofia? São Paulo: Ed. 34, 1992.

DELEUZE, G., GUATTARI, F. Introdução: Rizoma. In: DELEUZE, G., GUATTARI, F. Mil platôs: capitalismo e esquizofrenia. Rio de Janeiro: Ed. 34, 1995a. v.1, p.11-37.

DELEUZE, G., GUATTARI, F. 10.000 a.C.: a geologia da moral (Quem a Terra pensa que é?). In: DELEUZE, G., GUATTARI, F. Mil platôs: capitalismo e esquizofrenia. Rio de Janeiro: Ed. 34, 1995b. v.1, p.53-91.

DELEUZE, G., GUATTARI, F. 28 de novembro de 1947: como criar para si um Corpo sem Órgãos. In: DELEUZE, G., GUATTARI, F. Mil platôs: capitalismo e esquizofrenia. v.3. Rio de Janeiro: Ed. 34, 1996. v.3, p.9-29.

LAO-TZEU La voie et sa vertu: Tao-tê-king. Paris: Seuil, 1979.

SPINOZA, B. Ética. Madrid: Alianza Editorial, 1998.

TAUBER, A. I. Le rôle de Nietzsche dans l'élaboration de l'utopie médicale. In: SFEZ, L. (Org.) L'utopie de la santé parfaite: colloque de Cerisy. Paris: PUF, 2001. p.9-29.

TOURNIER, M. Sexta-Feira ou os limbos do Pacífico. São Paulo: Difel, 1985.

TEIXEIRA, R. R. La Gran Salud: una introducción a la medicina del Cuerpos sin Organos, Interface - Comunic., Saude, Educ., v.8, n.14, p.35-72, set.2003-fev.2004.

Partiendo de la Ética de Espinosa y, especialmente, de las lecturas de su filosofía practicadas por Deleuze \& Guattari, proponemos el concepto referencial de Gran Salud y esbozamos lo que podría ser la medicina referenciada en esa concepción. Otro concepto propuesto es el de Cuerpo sin Órganos, para sustentar el plano en que se experimenta la Gran Salud: plano de intensidades vivido como variación continua de las potencias, del apetito, del deseo. Esa lectura deleuzeana de Espinosa nos permite entrever las bases de una hipotética medicina espinosiana, con su Fisiología del Cuerpo sin Órganos, su "patología", aquí entendida como Afectología, su "ciencia de las señales y síntomas" o Semiótica y lo que sería su "terapéutica" orientada por el ideal de la Gran Salud.

PALABRAS CLAVE: Salud; Filosofía; Ética. 